NBER WORKING PAPER SERIES

\title{
MACROECONOMIC-DRIVEN PREPAYMENT RISK AND THE VALUATION OF MORTGAGE-BACKED SECURITIES
}

\author{
Mikhail Chernov \\ Brett R. Dunn \\ Francis A. Longstaff \\ Working Paper 22096 \\ http://www.nber.org/papers/w22096
NATIONAL BUREAU OF ECONOMIC RESEARCH
1050 Massachusetts Avenue
Cambridge, MA 02138 \\ March 2016
}

\begin{abstract}
We are grateful for the comments and suggestions of Vineer Bhansali, Nina Boyarchenko, Michael Brennan, Karen Chaltikian, Andrea Eisfeldt, Stuart Gabriel, James Gammill, David Langor, David Lucca, Xiaoxian Luo, Carolina Marquez, Ravi Mattu, Emmanuel Vallod, Victor Wong, and seminar participants at Blackrock, Boston College, Emory University, The Fink Center for Finance and Investments, Georgetown University, Georgia Institute of Technology, the University of British Columbia, the Spring 2015 Journal of Investment Management Conference, and UCLA. All errors are our responsibility. The views expressed herein are those of the authors and do not necessarily reflect the views of the National Bureau of Economic Research.
\end{abstract}

NBER working papers are circulated for discussion and comment purposes. They have not been peer-reviewed or been subject to the review by the NBER Board of Directors that accompanies official NBER publications.

(C) 2016 by Mikhail Chernov, Brett R. Dunn, and Francis A. Longstaff. All rights reserved. Short sections of text, not to exceed two paragraphs, may be quoted without explicit permission provided that full credit, including $\odot$ notice, is given to the source. 
Macroeconomic-Driven Prepayment Risk and the Valuation of Mortgage-Backed Securities

Mikhail Chernov, Brett R. Dunn, and Francis A. Longstaff

NBER Working Paper No. 22096

March 2016

JEL No. G12,G13

\begin{abstract}
$\underline{\text { ABSTRACT }}$
We introduce a reduced-form modeling framework for mortgage-backed securities in which we solve for the implied prepayment function from the cross section of market prices. From the implied prepayment function, we find that prepayment rates are driven not only by interest rates, but also by two macroeconomic factors: turnover and rate response. Intuitively, turnover represents prepayments for exogenous reasons like employment-related moves, household income shocks, and foreclosures, while rate response reflects frictions faced by borrowers in refinancing into a lower rate. We find that the empirical turnover and rate response measures are both significantly related to macroeconomic measures, suggesting that these factors represent a source of systematic risk. Consistent with this, we find that implied prepayments are substantially higher than actual prepayments, providing direct evidence of significant prepayment risk premia in mortgage-backed security prices. We analyze the properties of the prepayment risk premium and find that it is almost entirely due to compensation for turnover risk. We also find evidence that mortgage-backed security prices were significantly affected by Fannie Mae credit risk and the Federal Reserve's Quantitative Easing Programs.
\end{abstract}

Mikhail Chernov

UCLA

Anderson School of Management

110 Westwood Plaza, Suite C-417

Los Angeles, CA 90095

mikhail.chernov@anderson.ucla.edu

Brett R. Dunn

UCLA

110 Westwood Plaza

Los Angeles, CA 90095

Brett.Dunn.1@anderson.ucla.edu
Francis A. Longstaff

UCLA

Anderson Graduate School of Management

110 Westwood Plaza, Box 951481

Los Angeles, CA 90095-1481

and NBER

francis.longstaff@anderson.ucla.edu 


\section{INTRODUCTION}

A mortgage-backed security is a securitized claim to the principal and interest payments generated by a pool of fixed-rate mortgages. Mortgage-backed securities have traditionally been issued either by agencies such as Fannie Mae, Freddie Mac, and Ginnie Mae, or by private issuers. Agency mortgage-backed securities have the attractive feature that the timely payment of principal and interest is backed by either an implicit or explicit government guarantee. As of June 2015, the total notional amount of agency mortgage-backed securities outstanding was $\$ 7.171$ trillion, making this market one of the largest sectors of the global fixed income markets. ${ }^{1}$

Given the importance of the market, it is not surprising that much research has been devoted to the issue of how mortgage-backed securities should be valued. The first generation of pricing models treated mortgage prepayments as the result of a borrower attempting to maximize the value of an implicit interest rate option. Key examples include Dunn and McConnell (1981a, 1981b) and Brennan and Schwartz (1985). The second generation of pricing models is based on detailed econometric models of historical prepayment behavior. In these models, interest rate paths are simulated (under the risk-neutral measure) and the econometric prepayment model (estimated under the actual measure) is used to specify the cash flows along each interest rate path. Key examples include Schwartz and Torous (1989, 1992, 1993) and Richard and Roll (1989).

These types of models, however, have a number of important drawbacks. For example, prepayments are driven exclusively by interest rate changes in these models. Thus, by ruling out other possible sources of prepayments, the only risk premium allowed in these models is an interest rate risk premium - there is no scope for a separate prepayment risk premium. Furthermore, these models tend to produce prices that often diverge significantly from market prices, and can only be reconciled by introducing ad hoc "option-adjusted spreads" into the framework.

This paper presents a reduced-form framework for the valuation of mortgagebacked securities. This framework differs fundamentally from previous work in that we solve for the implied prepayment function rather than imposing an external prepayment model. A key advantage of this approach is that by studying the implied prepayment function, we can identify factors that the market views as important drivers of prepayment risk as well as the risk premia associated with those factors. The implied prepayment function is easily identified using

\footnotetext{
${ }^{1}$ See www.sifma.org/research/statistics.aspx.
} 
the information in the cross section of mortgage-backed securities with different coupon rates (the coupon stack). Our approach also allows for the possibility that mortgage cash flows may be discounted at higher rates than Treasuries because of either the perceived credit risk of the agency guaranteeing the mortgage-backed security, or the illiquidity of mortgage-backed securities themselves. We apply the framework to study the valuation of Fannie Mae mortgage-backed securities over the 1998-2014 period. A number of important results emerge from this analysis.

First, we find that implied prepayments are driven by interest rates as well as two additional macroeconomic risk factors: turnover and rate response. The turnover rate reflects prepayments occurring for exogenous reasons unrelated to interest rates, but possibly correlated with macroeconomic fluctuations. Examples include adverse income shocks or unemployment resulting in a move or a foreclosure, negative shocks to housing values resulting in underwater borrowers strategically defaulting on non-recourse loans, or homeowners with appreciated property taking cash-out mortgages to extract home equity. We find that the variation in the empirical turnover rate is strongly related to macroeconomic fundamentals such as consumption growth, changes in unemployment, and mortgage delinquencies. This suggests that turnover risk may be systematic in nature and carry a large risk premium. This is supported by evidence that the implied turnover rate is more closely related to returns in financial market than is the empirical turnover rate. The rate response factor represents the time variation in the sensitivity of refinancing activity to mortgage rate incentives. For example, borrowers may be less able to refinance into a lower mortgage rate after declines in housing prices, during recessions in which the borrowers' income or credit may have been impaired, or during periods in which mortgage lending standards are tightened. The results also provide evidence that this factor may be systematic in nature.

Second, we find that the implied prepayments on agency-guaranteed mortgages behave very differently than actual prepayments. For most mortgagebacked securities, implied prepayment rates are significantly higher than actual prepayment rates. This result provides some of the first direct evidence that the market incorporates significant prepayment-related risk premia into the prices of mortgage-backed securities, and may also explain why previous models based on empirical prepayment functions face challenges in their attempts to match the market prices of mortgage-backed securities.

Third, we study the determinants of the prepayment risk premium by mapping it into the risk premia associated with the turnover and rate response factors. We find that the turnover factor carries a large positive premium throughout the entire sample period, consistent with the systematic nature of turnover risk. In 
contrast, the risk premium for the rate response factor is slightly negative before the financial crisis, and becomes slightly positive after the crisis. Taken together, these results indicate that the large majority ( 84.50 percent) of the prepayment risk premium represents compensation for the risk of systematic or macroeconomic-driven shocks in the turnover rate.

Fourth, we find that cash flows from mortgage-backed securities are discounted at a rate 72 basis points higher on average than are cash flows from Treasuries. This spread varies significantly through time and is strongly correlated with the credit spread between Fannie Mae debt and Treasuries. Furthermore, the spread is significantly related to supply-related factors such as Federal Reserve purchases of mortgage-backed securities during its quantitative easing programs and changes in dealers' inventory positions of mortgage-backed securities. These results provide the first direct evidence that agency credit and liquidity spreads influence the pricing of mortgage-backed securities.

Finally, we show that this simple reduced-form valuation framework fits the market prices of mortgage-backed securities very closely. The median root mean squared error across the entire coupon stack is on the order of 27 cents per $\$ 100$ notional, which is on the same order of magnitude as the bid-ask spread for mortgage-backed securities. This accuracy compares very well to previous generations of valuation models for mortgage-backed securities. Furthermore, this result provides evidence that the pricing of mortgage-backed securities in the market may be much more rational than is commonly believed among market practitioners.

This paper contributes to the extensive literature on the pricing of mortgagebacked securities. Important recent work in this area includes Gabaix, Krishnamurthy, and Vigneron (2007) who study the pricing of interest-only strips and document that their option-adjusted spread covaries with the moneyness of the market, consistent with a prepayment risk premium and the existence of specialized mortgage-backed security investors. Boyarchenko, Fuster, and Lucca (2014) allow for the possibility that the implied prepayment rate may differ from the actual prepayment rate. They document an option-adjusted spread smile across mortgages with varying rates and use information from the interestonly/principal-only market to decompose the option-adjusted spread into its physical and risk-neutral components. They find evidence of a significant noninterest-rate-related prepayment risk premium in the components of the optionadjusted spread. This paper significantly extends the literature by using the entire cross section of mortgage-backed security prices to identify the implied prepayment function and its components, the associated prepayment risk premia, and the credit/liquidity component of mortgage-backed security prices.

The remainder of the paper is organized as follows. Section 2 provides a 
brief introduction to the agency mortgage-backed security market. Section 3 reviews the literature. Section 4 describes the data. Section 5 presents the valuation framework. Section 6 describes the implied prepayment model. Section 7 discusses the empirical methodology. Section 8 presents the empirical results for the implied prepayment function. Section 9 discusses the prepayment risk premium and its components. Section 10 makes concluding remarks.

\section{U.S. AGENCY MORTGAGE-BACKED SECURITIES}

Agency mortgage-backed securities are issued by Fannie Mae (FNMA), Freddie Mac (FHLMC), or Ginnie Mae (GNMA). ${ }^{2}$ Fannie Mae and Freddie Mac are government-sponsored enterprises (GSEs), whereas Ginnie Mae is a whollyowned government corporation. The U.S. agency mortgage-backed securities market is among the largest and most liquid bond markets worldwide. Furthermore, more than 70 percent of the $\$ 9.8$ trillion U.S. home mortgage market serves as collateral for agency mortgage-backed securities. Immediately prior to the financial crisis of 2007-2008, private financial institutions accounted for more than 50 percent of U.S. mortgage-backed security issuance. Since the crisis, however, "private label" issuance has declined dramatically and now represents less than four percent of total mortgage-related issuance. In contrast, agency mortgagebacked security issuance has grown rapidly; the total notional size of the agency mortgage-backed security market increased 58 percent from 2006 to $2015 .^{3} \mathrm{In}$ this section, we review the key features of agency mortgage-backed securities.

\subsection{Credit Quality}

In exchange for monthly fees, the agencies guarantee the timely payment of mortgage interest and principal. The guarantee protects investors from defaults on the underlying mortgages since delinquent mortgages must be purchased out of the trust at par by the issuer. This means that a default appears as a prepayment from an investor's perspective. Because GNMA securities carry the full faith and credit guarantee of the United States, their credit quality should be the same as that of U.S. Treasuries. FNMA and FHLMC securities carry a credit guarantee from the issuing GSE rather the United States. Historically, the GSE guarantee was viewed as an "implicit" government guarantee because investors believed

${ }^{2}$ Fannie Mae, Freddie Mac, and Ginnie Mae refer to the Federal National Mortgage Association, the Federal Home Loan Mortgage Corporation, and the Government National Mortgage Association, respectively.

${ }^{3}$ See Federal Reserve Board Flow of Funds Table L.217 and www.sifma.org/resea rch/statistics.aspx. 
that the government would back the agencies in times of stress. This view was validated in September 2008 when the government placed FNMA and FHLMC in conservatorship and provided them with unlimited access to collateralized funding. Both FNMA and FHLMC are supervised and regulated by the Federal Housing Finance Agency.

\subsection{Mortgage-Backed Security Cash Flows}

In this paper, we focus on agency mortgage-backed securities backed by pools of fixed-rate mortgages. A fixed-rate mortgage is structured so that the borrower is obligated to make the same payment each month, consisting of interest and principal. In general, fixed-rate mortgages can be prepaid at any time without penalty. Each month, therefore, a pool of mortgages generates cash flows consisting of scheduled interest, scheduled principal, and possibly prepaid principal. A pass-through mortgage-backed security distributes to investors the principal and interest payments from the underlying mortgage loans, less guaranty and servicing fees. Because the guaranty and servicing fees are based on the outstanding balance, these fees decline over the life of the mortgage. ${ }^{4}$

Mortgage servicers collect and aggregate payments from the underlying mortgage loans and pass the payments to the mortgage-backed security trust. Mortgage payments are due on the first of the month (with a grace period determined by state law). Investors, however, receive the payments after a delay of 14,19 , or 24 days, depending on the mortgage-backed security program. If a loan becomes delinquent, servicers advance scheduled principal and interest until either the loan becomes current or is bought out of the trust at par. Servicers retain a monthly fee based on a percentage of the outstanding mortgage balance at the beginning of the month. This fee is often referred to as a "servicing strip" because the cash flows resemble an interest-only strip. In the FNMA, FHLMC, and GNMA II programs, mortgages with different gross coupons can be pooled together as long as the net coupon (gross coupon minus servicing and guaranty fees) is identical among all the loans in the mortgage pool. In the GNMA I program, the gross coupon is always 50 basis points higher than the net coupon.

\subsection{Agency Mortgage-Backed Security Trading}

Agency mortgage-backed securities trade on either a to-be-announced (TBA) basis or a specified pool basis. The TBA market is a highly liquid forward market and accounts for 90 percent of all mortgage-backed security trading. From 2007 to 2014, the daily trading volume of U.S. agency mortgage-backed securities averaged $\$ 276$ billion, which compares well with the $\$ 525$ billion daily trading

\footnotetext{
${ }^{4}$ See www.fanniemae.com, www.freddiemac.com, and www.ginniemae.gov for more information about agency securitization programs.
} 
volume for U.S. Treasuries. Typically, pass-throughs are traded as specified pools if they command a premium over TBAs or if they are ineligible for TBA delivery. ${ }^{5}$

Similar to Treasury note and bond futures, a buyer of a TBA agrees to the trade without knowing the exact pools that will be delivered. Instead, the buyer and seller agree to six parameters: price, par amount, settlement date, agency program, mortgage type, and coupon. TBA trades generally settle to a monthly schedule set by the Securities Industry and Financial Markets Association (SIFMA). Nearly all TBA trades occur with settlement dates less than or equal to three months forward. Two days prior to the settlement date of the trade, the seller notifies the buyer of the exact pools that will be delivered (the 48-hour rule). The pools are then exchanged for the cash payment on the settlement date.

Market participants generally adhere to standards referred to as the "Good Delivery Guidelines" maintained by SIFMA. These guidelines specify the eligible collateral for a TBA trade and various operational guidelines such as the number of bonds per million dollars notional of a trade, the allowable variation in the delivery amount, and the costs of failing to deliver. TBA trades may also be executed with stipulations such as production year, weighted average maturity (WAM), weighted average loan age (WALA), FICO score, loan-to-value ratio, or geographic distribution. A stipulated TBA trade, however, would likely occur at a price higher than an unstipulated TBA.

\subsection{The Quantitative Easing Programs}

Table 1 provides a listing of the major events in the agency mortgage-backed securities market during the study period. Among the most significant of these events are the Federal Reserve's quantitative easing programs, commonly known as QE I, QE II, and QE III. The first program, QE I, was announced on November 25, 2008 and directed the purchase of up to $\$ 500$ billion of agency mortgagebacked securities and $\$ 100$ billion of GSE debt. The stated goal of QE I was to reduce the cost and increase the availability of credit for the purchase of houses. QE I was expanded on March 18, 2009 to allow additional purchases of up to $\$ 750$ billion of agency mortgage-backed securities and $\$ 100$ billion of agency debt. The QE II program was announced on November 3, 2010 and authorized the purchase of up to $\$ 600$ billion of longer-term Treasury securities. The QE III program was announced on September 13, 2012 and directed the purchase of up to $\$ 40$ billion per month of agency mortgage-backed securities and $\$ 45$ billion

\footnotetext{
${ }^{5}$ Trading volume data comes from FINRA TRACE https://www.finra.org/indus try/trace/structure-product-activity-reports-and-tables. See Vickrey and Wright (2013) for a discussion of the TBA market. Also see Carlin, Longstaff, and Matoba (2014).
} 
per month of Treasury securities. These programs had large effects on the supply of mortgage-backed securities in the market. ${ }^{6}$

\section{LITERATURE REVIEW}

Mortgage-backed security valuation is challenging because mortgage terminations (prepayments and defaults) may depend on many factors such as changes in interest rates, housing prices, employment status, family size, etc. For reviews of the literature, see Kau and Keenan (1995), Capone (2001), Hayre (2001), Wallace (2005), and Fabozzi (2006).

The first generation of pricing models was pioneered by Dunn and McConnell (1981a, 1981b) and extended by Brennan and Schwartz (1985). This framework approaches the valuation of mortgage-backed securities from the perspective of contingent claims theory. In particular, this approach models mortgage prepayments as the result of a borrower attempting to maximize the value of an implicit interest rate option. Dunn and Spatt (2005) and Stanton and Wallace (1998) extend the approach to model the prepayment decision as the result of minimizing lifetime mortgage costs in the presence of refinancing costs. These papers, however, imply an upper bound on mortgage prices that is often violated empirically, as demonstrated by Stanton (1995) and Boudoukh, Richardson, Stanton, and Whitelaw (1997). Later papers add frictions to allow for higher mortgage prices and consider the value of the prepayment option jointly with the option to default. Important contributions are Titman and Torous (1989), Kau, Keenan, Muller, and Epperson (1992), and Kau and Slawson (1995), Downing, Stanton, and Wallace (2005), Longstaff (2005), and many others. An important drawback of this modeling approach is that actual borrowers generally do not follow the prepayment strategies implied by these models. Thus, actual mortgage cash flows and mortgage-backed security prices often diverge significantly from those implied by these types of models.

The second generation of mortgage-backed security pricing models takes a more empirical approach. Typically, these models begin with a detailed econometric model of the historical behavior of prepayments, including elements such as geography, seasoning, burnout, seasonality, and other factors. Key examples of this approach include Schwartz and Torous (1989, 1992, 1993), Richard and

\footnotetext{
${ }^{6}$ For a detailed discussion of the effects of the quantitative easing programs, see Gagnon, Raskin, Remache, and Sack (2011), Krishnamurthy and VissingJorgensen (2011, 2013), Christensen and Rudebusch (2012), Thornton (2014), and Christensen and Gillan (2015).
} 
Roll (1989), and Deng, Quigley, and Van Order (2000). In this framework, interest rate paths are simulated (under the risk-neutral measure) and the econometric prepayment model (estimated under the actual measure) is applied to specify the cash flows along each interest rate path. Important drawbacks of this modeling approach include the fact that, by using an empirical prepayment model, this approach does not allow for the possibility of a prepayment risk premium. In particular, this approach requires that prepayment dynamics be the same under risk-neutral and actual measures. In actuality, market participants disagree significantly about prepayment forecasts (see Carlin, Longstaff, and Matoba (2014)). The net effect of these factors is that the prices implied by market participants' models often diverge significantly from market prices. These differences are typically expressed in terms of a yield spread adjustment to discount rates, known as the option-adjusted spread.

Given the inconsistent use of risk-neutral and actual measures in solving for the option-adjusted spread, it is not surprising that the economic interpretation of the option-adjusted spread is murky, and its values are frequently more volatile than the underlying mortgage-backed security prices. To illustrate this, Figure 1 plots the time series of option-adjusted spreads for FNMA 6.50 percent mortgage-backed securities as implied by the sequence of pricing models used by a major Wall Street mortgage dealer. As shown, the dealer changed its model frequently during the 2007-2015 period, primarily because the prior version of the model was failing to capture current market prices. The plot shows that changes in the model are often associated with large discontinuities in the time series of the option-adjusted spread that can be on the order of 100 basis points or more. This erratic behavior in the option-adjusted spread, even when holding the dealer fixed, provides a strong argument for basing empirical analysis on mortgage-backed security prices directly, rather than on option-adjusted spreads. This point is reinforced further by the evidence in Carlin, Longstaff, and Matoba (2014) that there is significant disagreement across dealers in terms of forecasted prepayment speeds, which would, in turn, translate into large differences in option-adjusted spreads across dealers.

Levin and Davidson (2005) attribute the variability in option-adjusted spreads to a prepayment risk premium and suggest a method to use market prices to adjust the empirical prepayment process for prepayment risk. Gabaix, Krishnamurthy, and Vigneron (2007) study the pricing of interest-only strips and document that their option-adjusted spread covaries with the moneyness of the market, consistent with a prepayment risk premium and the existence of specialized mortgage-backed security investors. Boyarchenko, Fuster, and Lucca (2014) document an option-adjusted spread smile across mortgages with varying rates and use information from the interest-only/principal-only market to decompose option-adjusted spreads into their physical and risk-neutral compo- 
nents. Their work includes the important insight that information about the risk-neutral prepayment rate can be extracted from interest-only/principal-only securities. Other important recent contributions in understanding the economics of mortgage-backed security markets include Cheyette (1996), Linetsky (2004), Goncharov (2006), Gorovoy and Linetsky (2007), Malkhozov, Mueller, Vedolin, and Venter (2014), Hanson (2014), and Song and Zhu (2015).

\section{THE DATA}

The primary data for the study consist of monthly prices (observed at the end of each month) from the TBA market for FNMA mortgage-backed securities with varying coupons. The sample period is January 1998 to September 2014. The data are obtained from a proprietary data set compiled by a major Wall Street mortgage-backed security dealer. However, we have cross validated the proprietary data with prices publicly available in the Bloomberg system and found the two sources to be very similar. To insure that we include only prices for actively traded mortgage-backed securities, we limit the data set to mortgage-backed securities with coupon rates that are within 300 basis points of the current coupon mortgage rate. The data set also includes three-month horizon conditional prepayment rate (CPR) information for each coupon.

Table 2 presents summary statistics for the data. As shown, the sample includes mortgage-backed securities with coupons ranging from 2.50 percent to 9.50 percent. Of course, not all coupons are actively traded throughout the entire sample period. The higher coupon mortgage-backed securities appear during the early part of the sample period when mortgage rates are considerably higher, and vice versa for the lower coupon mortgage-backed securities.

We also collect data for a wide variety of macroeconomic, mortgage market, and financial variables that will be used in the analysis throughout the paper. The Appendix provides a description of each of these variables and the sources of the data.

Finally, we collect historical data on Treasury constant maturity rates from the Federal Reserve H.15 release. We use a standard cubic spline approach to bootstrap the prices of zero-coupon bonds $D(t)$ for maturities ranging up to 30 years for each month during the sample period (methodology is described in the Appendix). 


\section{THE REDUCED-FORM FRAMEWORK}

In valuing mortgage-backed securities, we use a reduced-form framework in which an instantaneous prepayment process $p_{t}$ plays the central role. Specifically, $p_{t}$ is the fraction of the remaining notional balance of the underlying mortgage pool that is prepaid each instant. Thus, $p_{t}$ can be viewed as a prepayment intensity or hazard rate. ${ }^{7}$ Our approach will be to solve for the implied value of $p_{t}$ and its dynamics from the cross section and time series of prices of mortgage-backed securities with different mortgage rates.

For expositional clarity, we assume for the present that mortgage cash flows are paid continuously and that the fixed mortgage rate $m$ on the mortgages in the underlying pool is the same as the coupon rate on the mortgage-backed security. Let $c$ denote the payment on a mortgage with an initial principal balance of one. Since the present value of the mortgage equals one at inception,

$$
\begin{aligned}
1 & =c \int_{0}^{T} e^{-m t} d t, \\
& =(c / m)\left(1-e^{-m T}\right),
\end{aligned}
$$

and the mortgage payment $c$ is,

$$
c=\frac{m}{1-e^{-m T}} .
$$

Let $I_{t}$ denote the principal balance of the mortgage at time $t$. The change in the principal balance is just the difference between the interest on the mortgage balance and the mortgage payment,

$$
d I_{t}=m I_{t}-c
$$

Solving this first-order differential equation subject to the initial condition implies

$$
I_{t}=\frac{1-e^{-m(T-t)}}{1-e^{-m T}} .
$$

\footnotetext{
${ }^{7}$ The proportional rate $p_{t}$ at which loans are being prepaid is often referred to as the CPR of the mortgage-backed security by market participants.
} 
Now, consider a mortgage-backed security where the individual mortgages in the underlying pool are all $T$-year fixed-rate mortgages. Without loss of generality, we normalize the initial notional balance of the pool to be one. We denote the remaining notional balance of the underlying pool at time $t$ as $N_{t}$, which, given the definition of $p_{t}$, can be expressed as

$$
N_{t}=\exp \left(-\int_{0}^{t} p_{s} d s\right)
$$

In turn, the remaining principal balance of the underlying pool is given by $N_{t} I_{t} .{ }^{8}$

Finally, let $F(m, T)$ denote the value of a mortgage-backed security where the underlying mortgages have a mortgage rate of $m$ and maturity of $T$. The value of the mortgage-backed security at time zero is given formally by

$$
F(m, T)=E^{Q}\left[\int_{0}^{T} \exp \left(-\int_{0}^{t} r_{s}+w_{s} d s\right) N_{t}\left(c+p_{t} I_{t}\right) d t\right]
$$

where $E^{Q}[\cdot]$ denotes expectation under the risk neutral measure, $r_{t}$ is the riskless interest rate, and $w_{t}$ plays the role of a credit/liquidity spread. The rationale for including $w_{t}$ in the model is to allow for the possibility that cash flows from agency mortgages may be discounted a higher rate than Treasury cash flows, either because the credit risk of the agency may not be as strong, or because agency mortgages may be less liquid than Treasuries.

\section{THE PREPAYMENT FUNCTION}

To complete the valuation framework for mortgage-backed securities, we need to specify the prepayment process $p_{t}$. Before doing this, however, it is useful to first consider some of the stylized facts about actual prepayment rates.

To illustrate the relation between prepayments and refinancing incentives, Figure 2 plots the prepayment rates for FNMA mortgage-backed securities as functions of the prices of these securities. As shown, there is a strong relation

\footnotetext{
${ }^{8}$ It is important to distinguish between the remaining notional amount and the principal balance since mortgage payments are based on the original notional amount of the mortgages while prepayment cash flows are based on the remaining principal balance.
} 
between the prepayment rate and the price of the mortgage-backed securities. When the price of the mortgage-backed security is less than 100, the coupon rate on the mortgage is lower than the current market rate, and the borrower has no incentive to refinance. When the price is greater than 100, however, the borrower may be able to reduce his mortgage costs by refinancing. Interestingly, the relation between prepayment rates and mortgage prices has the appearance of a piecewise linear function similar to that of a call option payoff.

In particular, when the price of the mortgage-backed security is less than 100 , the relation is flat, although generally not zero. In fact, the prepayment rates for these mortgage-backed securities can be as high as 10 to 15 percent, because borrowers often prepay mortgages for reasons other than to reduce mortgage costs. For example, borrowers often prepay mortgages even when the market rate is higher than their mortgage rate for exogenous reasons such as a retirement or a career-related move. Also, borrowers may refinance into a higher mortgage rate to extract home equity after an increase in housing prices. During the recent financial crisis, a major source of exogenous prepayments has been the high rate of foreclosures throughout the U.S. (a foreclosure results in the pass through of the entire remaining mortgage balance to the holders of an agency-guaranteed mortgage-backed security).

When the price of the mortgage-backed security is greater than 100, the relation is generally increasing, but spreads out as the price increases. A closer inspection of the data, however, indicates that the relation is actually close to linear at a point in time, but that the slope of the relation varies over time. Thus, the unconditional relation appears spread out. To illustrate this, Figure 3 plots the prepayment rate and price relation for selected dates during the sample period. As shown, the prepayment functions display varying slopes over time.

Motivated by these stylized facts, we use a simple generic specification of the implied prepayment function that allows for both exogenous and rate-related prepayments. Specifically, we model the prepayment function as

$$
p_{t}=x_{t}+y_{t} \max \left(0, m-a-b r_{t}\right)
$$

In this specification, $x_{t}$ denotes the exogenous hazard rate at which mortgages are prepaid in the absence of refinancing incentives. Intuitively, $x_{t}$ captures all the non-interest-rate-related background factors that lead to prepayments. Thus, we will refer to $x_{t}$ simply as the turnover rate.

The refinancing incentive is determined by the difference between the mortgage rate $m$ and the implied rate at which mortgages can be refinanced. We allow this implied rate to be a general affine function $a+b r_{t}$ of the short-term 
riskless rate, rather than constraining it to be a specific short-term or long-term rate. The values of $a$ and $b$ will be estimated from the data.

The term $y_{t}$ which multiplies the refinancing incentive term $\max (0, m-$ $a-b r_{t}$ ) in Equation (8) measures how sensitive borrowers are to refinancing in-

centives. For example, a borrower whose house value was less than the mortgage balance would typically have a very low propensity to refinance, or equivalently, a low value of $y_{t}$. After the introduction of the Home Affordable Refinancing Program (HARP) in 2009, however, the same borrower might have been much more likely to refinance given the same level of refinancing incentive. Similarly, the propensity to refinance could also vary with the required loan-to-value standards in the mortgage market. Given the role that $y_{t}$ plays in the prepayment function, we denote it as the rate response factor.

\section{ESTIMATION METHODOLOGY}

In this framework, the value of a mortgage-backed security is a function of the three state variables: $w_{t}, x_{t}$, and $y_{t}$ (in addition to the interest rate). To complete the specification of the model, we assume that the dynamics of the state variables are given by the following system of stochastic differential equations under the risk-neutral pricing measure,

$$
\begin{aligned}
d w & =\left(\alpha_{w}-\beta_{w} w\right) d t+\sigma_{w} d Z_{w}, \\
d x & =\left(\alpha_{x}-\beta_{x} x\right) d t+\sigma_{x} \sqrt{x} d Z_{x}, \\
d y & =\left(\alpha_{y}-\beta_{y} y\right) d t+\sigma_{y} \sqrt{y} d Z_{y} .
\end{aligned}
$$

where the Brownian motions are independent of each other. The credit/liquidity spread $w_{t}$ follows a mean-reverting process that can take on both positive and negative values, paralleling the specification used by Duffie and Singleton (1997, 1999), Longstaff, Mithal, and Neis (2005), and many others. The state variables $x_{t}$ and $y_{t}$ driving prepayments both follow mean-reverting square-root processes, ensuring that prepayment rates are always nonnegative. Note that this specification of dynamics places this model within the familiar affine framework widely used throughout the financial literature.

To model the evolution of the riskless rate, we assume that $r_{t}$ follows the single-factor Vasicek (1977) process. This assumption, however, can easily be relaxed to allow for a more general multi-factor specification. The riskless rate is assumed to be independent of the other state variables. 
The estimation of the model can be viewed as consisting of three steps. First, we select an initial parameter vector $\theta$, where $\theta=\left\{a, b, \alpha_{w}, \alpha_{x}, \alpha_{y}, \beta_{w}, \beta_{x}, \beta_{y}\right.$, $\left.\sigma_{w}, \sigma_{x}, \sigma_{y}\right\}$. Second, conditional on $\theta$ and for each month $t$ during the sample period, we solve for the values of $w_{t}, x_{t}$, and $y_{t}$ that best fit the model to the prices for the coupon stack (the cross section of mortgage-backed securities with different coupon rates) by minimizing the root mean squared error (RMSE). Since the nonlinear structure of the prepayment function makes it difficult to express the price of mortgage-backed securities in closed-form, we use simulation to solve for the model-based mortgage-backed security values. Third, we iterate over alternative values of the parameter vector $\theta$ until we find the vector that results in the lowest global root mean square error (RMSE). Table 3 reports the parameter values obtained from the estimation along with their asymptotic standard errors. The outputs are the parameter values and the time series of state variables.

The details of the estimation process are described in the Appendix. As discussed, the parameters for the riskless rate are estimated separately. Specifically, we use an approach in which we fit exactly the ten-year spot rate for each month in the sample period, and adjust the volatility parameter of the Vasicek model each month to match the basis point volatility of a one-year into ten-year swap option. The results, however, are very robust to the specification of the interest rate model.

\section{THE IMPLIED PREPAYMENT FACTORS}

In this section, we discuss the empirical results and their implications. First, we examine how well the model is able to fit the market prices of mortgage-backed securities. We then study the properties of the three state variables of the model: the credit/liquidity spread $w_{t}$, the turnover rate $x_{t}$, and the rate response factor $y_{t}$.

\subsection{Fitting Mortgage-Backed Security Prices}

The coupon stack for each month in the sample period typically includes between 6 to 10 mortgage-backed securities with varying coupon rates at 50 basis point increments. The estimation algorithm solves for the values of the three state variables $w_{t}, x_{t}$, and $y_{t}$ that best fit the model to the coupon stack. Since there are more prices than state variables, it is clear that there will be residual differences between model values and market values. To quantify the magnitude of these differences, we compute the RMSE for each month in the sample period. 
Figure 4 plots the time series of the RMSEs. As shown, the model fits the mortgage-backed security prices extremely well. For much of the sample period, the RMSEs range from about 5 to 30 cents for mortgage-backed security prices quoted in terms of a $\$ 100$ notional position. This range compares reasonably well with the bid-ask spreads of actively-traded mortgage-backed securities, which discussions with traders indicate are typically on the order of three to four ticks, or 32 nds of a point. Once the financial crisis begins in 2008, however, the RMSEs tend to become larger in value. Intuitively, this may simply be the result of the massive shocks that the housing and mortgage markets experienced during the financial crisis, as well as a lack of liquidity and risk capital in the markets to arbitrage mispricing among mortgage-backed securities. The median RMSE for the pre-crisis period is 23.8 cents. The median RMSE for the entire sample period is 27.3 cents.

\subsection{The Mortgage-Backed Security Pricing Factors}

The estimation algorithm solves for the implied values of the three factors driving mortgage-backed securities prices for each month during the sample period: the credit/liquidity spread, the turnover rate, and the rate response factor. Table 4 provides summary statistics for the implied values of these factors. These pricing factors are discussed individually below.

\subsection{The Credit/Liquidity Spread}

Table 4 shows that the mean value of the credit/liquidity spread is about 72.1 basis points with a standard deviation of 52.2 basis points. This mean value is in relatively close agreement with the average spread on FNMA debt issues during the sample period. For example, the average spread of FNMA ten-year debt over Treasuries during the January 2000 to September 2014 period is 49.8 basis points. We will study the link between the implied spread and FNMA credit spreads in more depth shortly.

Figure 5 plots the time series of the implied credit/liquidity spread values over the sample period, along with the spread for FNMA agency debt. As shown, the majority of the implied spreads are positive. In particular, 178 or 88.6 percent of the 201 estimates are positive. The fact that some of the implied spreads are negative, however, hints that the implied spreads may be reflecting more than the credit risk of FNMA bonds, particularly since FNMA credit spreads are uniformly positive throughout the 2000-2014 period.

This latter observation is reinforced by comparing the spread values shown 
in Figure 5 with the key events in the timeline given in Table 1. For example, the downward spike around April 2009 coincides with the large expansion of the QE I program to purchase an additional $\$ 750$ billion of MBS. The very large downward spike around September 2012 coincides with the announcement of the QE III program to purchase $\$ 40$ billion of agency MBS per month. Thus, these observations hint that the massive purchases of MBS during QE I and QE III may have had an effect via new production and existing collateral being removed from the market. The potential effect is two-fold: a direct decrease in supply would increase prices and decrease spreads, an indirect effect on liquidity would increase spreads. It appears that the first effect dominates the second.

On the other hand, Figure 5 also shows that the implied spreads appear to be correlated with key events that may impact the credit risk of FNMA. For example, the local minimum in the spread during the early part of 2005 coincides with a period when the mortgage delinquency rate reached historically low values (the calm before the storm). Similarly, the spread attains its largest values during the Lehman crisis period of Fall 2008. However, after FNMA and FHLMC are placed into conservatorship and their credit risk is essentially defeased, the implied spread quickly returns to pre-crisis levels, and subsequently actually reaches historical lows.

To examine the properties of the implied spread in more detail, we regress monthly changes in the spread on a number of explanatory variables reflecting changes in the credit risk and liquidity of the mortgage-backed securities market. First, we include monthly changes in the yield spread between FNMA notes and Treasury notes with similar maturities. The intuition for including this spread is that if FNMA's cost of debt capital were to increase relative to that of the Treasury, then the value of the FNMA guarantee should decline, resulting in lower mortgage-backed security prices, or equivalently, higher implied spreads. Second, we include current and lagged changes in primary dealers' holdings of mortgagebacked securities as reported by the Federal Reserve Bank of New York. The intuition for this measure is that when primary dealers increase their inventories, we would expect that the liquidity of the mortgage-backed securities market would improve, leading to a decline in the implied spread. Third, we include changes in the general collateral repo rate in the regression. Because the repo rate reflects the cost to a mortgage-backed securities dealer of financing inventory, an increase in the repo rate would provide dealers with a strong incentive to reduce inventory, allowing investors to purchase mortgage-backed securities at better prices or lower spreads. Finally, we include several measures relating to the supply of mortgage-backed securities in the market. The first is the net issuance of mortgage-backed securities. The second is the ratio of Federal Reserve purchases of mortgage-backed securities to total net issuance. This ratio reflects how much of the flow of issuance is being absorbed by the Federal Reserve. A 
high value for this ratio could imply that dealers are being crowded out of the market, potentially impairing market liquidity. We also include the lagged value of the change in the spread as a control variable.

Table 5 presents the regression results. As illustrated, the change in the FNMA credit spread is strongly related to the change in the credit/liquidity spread implied from the prices of mortgage-backed securities. The regression coefficient is positive and highly significant with a $t$-statistic of 9.12. Although this result is very intuitive, to our knowledge, this is the first direct evidence that the credit risk of the agency guaranteeing the timely payment of principal and interest is related to the pricing of mortgage-backed securities. The regression coefficient of roughly 0.84 indicates that while the implied spread is closely related to the spread on FNMA debt, the relation is not one-to-one and that there are other drivers of the implied spread.

In particular, Table 5 shows that the coefficient for the lagged change in primary dealers' inventory is negative and significant. The negative signs for both the current and lagged changes are consistent with the view that the implied spread also reflects the overall liquidity of the mortgage-backed securities market. Specifically, that when primary dealers increase their inventory, the liquidity of the market increases, resulting in a decline in the implied spread.

Table 5 also show that there is a significant positive relation between changes in the implied spread and ratio of Federal Reserve purchases to total net issuance of mortgage-backed securities. This result is consistent with the interpretation that the large purchases of mortgage-backed securities during the quantitative easing programs crowded out other players in the market and adversely affected liquidity.

Given the strong empirical relation between the credit/liquidity rate and the FNMA credit spread, a simple estimate of the size of the liquidity component in mortgage-backed securities could be obtained by subtracting the FNMA credit spread from the credit/liquidity spread. Figure 6 plots this estimate of the liquidity spread. As shown, during the pre-crisis period, the liquidity spread is positive with an average value of around 25 basis points. The liquidity spread spikes during the period leading up to the Lehman default and the conservatorship of Fannie Mae and Freddie Mac in September 2008. Afterwards, however, the liquidity spread declines to near zero with downward spikes coinciding with the initiation and extension of the QE I program. The initiation of the QE III program with its massive purchases of agency mortgage-backed securities coincides with the large negative spike in the liquidity spread. Discussions with industry sources suggest that as the Federal Reserve's purchases of agency mortgage-backed securities began to crowd other players out of these markets, the difficulty of finding tradeable collateral made existing supplies of mortgage-backed securities trade 
at a premium. The liquidity estimates shown in Figure 6 are consistent with this view.

\subsection{The Turnover Rate}

The implied turnover rate is based on the risk-neutral measure since its value is inferred from the prices of mortgage-backed securities. Because prepayment rates are directly observable, however, the turnover rate under the actual or empirical probability measure is easily estimated from the data. ${ }^{9}$ As part of our analysis, we will contrast the properties of the empirical and implied turnover rates and examine their implications for risk premia.

Table 4 shows that the mean value of the implied turnover rate is about 17.2 percent. As we discuss later, this is higher than the observed refinancing rate for mortgages with coupon rates below the current market mortgage rate.

To explore this further, we regress quarterly changes in both the empirical and implied turnover rates on variables that reflect the degree of financial distress in the mortgage markets and the state of the macroeconomy. As proxies for financial distress, we include the change in the mortgage foreclosure rate and the lagged change in the mortgage deliquency rate (both from the Mortgage Bankers Association National Delinquency Survey). As macroeconomic measures, we include the lagged growth rate in US personal consumption expenditures and the change in the US unemployment rate. The reason for focusing on quarterly changes in the regression is that a number of the explanatory variables are only observed quarterly. We include the contemporaneous value of some variables and the lagged value for others (rather than including both values) simply because the limited number of observations necessitates a parsimonious specification. Thus, we report results including only the value of each variable that appears to have the most explanatory power. We note that the empirical results are largely unaffected by this simplification.

We also include variables that may reflect various dimensions of the wealth and consumption incentives of mortgage borrowers. In particular, we include the return on the Barclays US Aggregate Bond Index, the lagged return on the CRSP value-weighted stock index, and the lagged change in the National Association of Home Builders Market Index. Finally, we also include the change in the fraction of refinanced mortgages where the new balance is more than five percent higher

\footnotetext{
${ }^{9}$ We estimate the empirical turnover rate for each month during the sample period by simply taking the average prepayment rate for all mortgage-backed securities trading at a price below 100 that month.
} 
than the balance on the refinanced loan, obtained from Freddie Mac's Cash-out Refinance Report. These types of loans are known as cash-out mortgages since the borrower ends up with additional cash. An increase in the fraction of cash-out mortgages could signal that borrowers are refinancing for consumption reasons (rather than interest-rate-related reasons) such as extracting equity from a home after housing values increase. We also include the lagged change in the turnover rate as a control for time series effects.

Table 6 reports the results from the regression. Focusing first on the regression for changes in the actual turnover rate, the results show that turnover is strongly related to changes in the state of the mortgage market as well as general macroeconomic conditions. In particular, an increase in the delinquency rate is significantly positively related to subsequent turnover. This is intuitive since higher delinquencies forecast future foreclosures. In contrast, the change in the current foreclosure rate is significantly negatively related to actual turnover. This suggests that by removing problem loans from the underlying pool via foreclosure, the average quality of the remaining loan pool improves and uncertainty about credit outcomes is resolved. The coefficient for the change in the unemployment rate is positive and significant, consistent with the interpretation that involuntary turnover increases during economic downturns as borrowers face adverse shocks and distress-related prepayments increase (via foreclosures, employment-related moves, etc.). On the other hand, the coefficient for consumption growth is positive and significant, consistent with the view that voluntary mortgage turnover may increase when borrowers increase their consumption of housing by selling and moving up to more expensive homes, etc. This interpretation is also consistent with the significant positive coefficients for lagged stock returns and the housing index, which suggest that as asset values increase, voluntary turnover also increases.

Turning our attention now to the regression for changes in implied turnover, we see that implied turnover behaves very differently from actual turnover. In particular, none of the macroconomic and mortgage market financial distress variables are significant in this regression. Instead, changes in implied turnover are strongly related to returns in other markets. For example, the coefficients for bond returns, stock market returns, and changes in the housing market index (at the ten-percent level) are all significant. These results suggest that the implied turnover rate may include financial risk premia correlated with those in other financial markets. Furthermore, changes in the implied turnover rate are significantly positively related to cash-out mortgage activity.

In summary, the relation between actual turnover rates and macroeconomic factors such as consumption growth, unemployment, and financial distress in the housing markets suggests that turnover risk may be very systematic in nature. 
If so, it would not be surprising if turnover risk were to carry a large risk premium. This possibility is strengthened by finding that changes in the implied turnover rate are more strongly correlated with financial market returns than with macroeconomic fundamentals. We will explore this issue in depth later in the paper.

\subsection{The Rate Response Factor}

Table 4 reports summary statistics for the implied rate response factor. As in the previous section, we explore the properties of the rate response factor by regressing quarterly changes in its empirical and implied values on variables that may reflect the frictions borrowers face in refinancing mortgages. ${ }^{10}$

The first set of variables are chosen to proxy for mortgage credit conditions. In particular, we include the change in the bank tightening index which measures the fraction of bank loan officers who describe the trend of credit availability as tightening (from the Federal Reserve's Senior Loan Officer Opinion Survey on Bank Lending Practices). We also include the change in the average loan-to-value ratio for all conventional mortgages. These loan-to-value statistics are compiled and reported by the Federal Housing Finance Agency. A decrease in the average loan-to-value ratio would be consistent with the scenario in which lenders are tightening mortgage credit, and vice versa. Finally, we include the change in the total amount of nonmortage consumer credit outstanding as reported by the Federal Reserve Board. Changes in this index may reflect fundamental changes in the availability of credit to borrowers.

Since the credit frictions faced by mortgage borrowers may also depend on macroeconomic conditions, we also include a number of macroeconomic measures in the regression. As before, we include the lagged growth rate in US personal consumption expenditures. We also include the change in the Conference Board's Consumer Confidence Index, and the change in the unemployment rate.

Finally, we again include variables that may be related to the wealth of mortgage borrowers since this could potentially affect their ability to refinance: the return on the Barclays US Aggregate Bond Index, the lagged return on the CRSP value-weighted stock index, and the lagged change in the National

\footnotetext{
${ }^{10}$ The empirical rate response factor is estimated for each month during the sample period by regressing the observed prepayment rates for the mortgagebacked securities with prices above 100 on the refinancing incentive (defined as the difference between the mortgage coupon rate and the current coupon mortgage rate).
} 
Association of Home Builders Housing Market Index.

Table 7 reports the results from the regressions. Beginning again with the results for the empirical rate response factor, we find that none of the three mortgage credit condition proxies (the bank tightening index, the average loanto-value ratio, and the amount of consumer credit) are significant. On the other hand, the results indicate that both the lagged consumption growth rate and change in consumer confidence are significant. The negative signs for these variables, however, are perplexing since they suggest that frictions are higher as macroeconomic conditions improve. One possible interpretation of this is that borrowers pay less attention to refinancing when macroeconomic conditions are strengthening and their individual financial situations improve. The strong link between macroeconomic conditions and the rate response factor again argues that the market may view this factor as a systematic risk which should carry a risk premium. Finally, neither the bond, stock market, nor housing market measures are significant.

The results for the implied rate response factor are again very different from those for the empirical factor. As before, the link between macroeconomic variables and the implied factor is much weaker. Furthermore, there is a strong correlation between the implied rate response factor and both the bond market return and changes in the housing index. This again suggests that a major component of the implied rate response factor may represent a risk premium compensating investors for the systematic nature of the variation in this factor.

\section{THE PREPAYMENT RISK PREMIUM}

In this section, we examine whether the market prices of mortgage-backed securities incorporate a risk premium for prepayment risk. Since we model prepayment risk as an explicit function of the turnover rate and the rate response factor, our framework also allows us to break down the total prepayment risk premium further into the components related to the turnover rate and the rate response factor.

We note that mortgage-backed securities may also incorporate premia for interest rate risk and agency credit risk. Rather than focusing on these wellknown and extensively-researched types of risk premia, however, we will focus exclusively on the prepayment risk premium since there has been relatively little previous research on this topic in the literature.

\subsection{Is there a Prepayment Risk Premium?}


To address the issue of whether there is a prepayment risk premium, we follow the standard approach of comparing values estimated under the risk-neutral pricing measure with those estimated under the actual or objective measure. Because the implied prepayment function is estimated directly from the market prices of mortgage-backed securities, it represents the prepayment function under the riskneutral pricing measure. In contrast, prepayments under the actual or empirical measure are directly observable.

It is important to observe that since the prepayment rate represents a riskneutral hazard rate or probability in this framework, the implied value of the turnover rate need not equal the empirical turnover rate. This follows from Jarrow, Lando, and Yu (2005) who show that if hazard rates or intensities are sensitive to shocks that carry risk premia (for example, such as macroeconomic factors), then their values can differ between the risk-neutral and actual measures. This is analogous to what occurs in reduced-form credit models in which the risk-neutral default probability or hazard rate need not equal the actual default probability. A key difference, however, is that the actual probability of default is extremely difficult to measure given how rare default events are. Thus, it is very challenging to estimate the difference between risk neutral and actual default probabilities. ${ }^{11}$ In contrast, empirical prepayment rates are directly observed and differences between the prepayment rate under the risk neutral and objective measures are easily identified.

The implied prepayment rate for each mortgage-backed security is given by simply substituting its weighted average coupon rate into the fitted prepayment function. Observe that in doing this, we are solving for the instantaneous implied prepayment rate which can be compared directly to the three-month realized CPR for the mortgage-backed security. ${ }^{12}$

The upper panel of Figure 7 plots the time series of the monthly averages for both the implied and empirical prepayment rates. The bottom panel plots the time series of the prepayment risk premium which is computed as the difference between the implied and realized prepayment rates. As shown in the upper panel, the implied and realized prepayment rates generally track each other over time, but there are some notable exceptions, particularly during the peak of the financial crisis. This is particularly evident in the lower panel which shows that the prepayment risk premium reached extreme values during late 2008 and early 2009 .

\footnotetext{
${ }^{11}$ For example, see Huang and Huang (2012) and Giesecke, Longstaff, Shaeffer, and Strebulaev (2011).

${ }^{12}$ To solve for the risk premium over longer horizons, we would need also need to solve for the parameters of the $w, x$, and $y$ processes under the objective measure.
} 
The upper panel of Table 8 presents summary statistics for the implied prepayment rates, the empirical prepayment rates, and the prepayment risk premium. To make the results more interpretable, we first compute the average implied and actual prepayment rates across all coupons for each month. The summary statistics in Table 8 are then computed using the time series of the monthly averages.

As shown, the average implied prepayment rate across the entire sample of mortgage-backed securities is 37.257 percent. In contrast, the average empirical prepayment rate for the same sample of mortgage-backed securities is 21.241 percent. Thus, the implied prepayment function is clearly very different from the actual prepayment function. The average difference between the implied and actual prepayment rates is 16.015 percent. The hypothesis that this difference is zero is strongly rejected by the data. These results provide direct confirmation that there is a substantial prepayment risk premium incorporated into mortgage-backed security prices. This direct evidence of prepayment risk premia in the mortgage-backed securities market corroborates the evidence of prepayment risk premia in the option-adjusted spreads of interest-only/principal-only securities reported by Gabaix, Krishnamurthy, and Vigneron (2007) and Boyarchenko, Fuster, and Lucca (2014).

On average, the implied prepayment rate is substantially higher than the empirical prepayment rate. This has important implications for the pricing of mortgage-backed securities. In particular, the prices of mortgages with coupon rates below the current market rate are increasing in the prepayment rate while the opposite is true for the prices of mortgages with coupon rates higher than the current market rate. Thus, the positive prepayment risk premium implies that discount mortgages will have higher values than implied by empirical prepayment functions, while the reverse will be the case for premium mortgages. These results are broadly consistent with the empirical evidence provided in Duarte, Longstaff, and $\mathrm{Yu}(2007)$.

To provide a cross sectional perspective, Figure 8 presents a scatter diagram of the prepayment risk premium for the individual mortgage-backed securities in the sample against their price. As shown, there is clearly heterogeneity in the prepayment risk premium across mortgages with different coupons. For example, although the risk premium is positive on average across all mortgages, there are clearly more negative values for mortgage-backed securities with prices in excess of 100. The average prepayment risk premium for mortgage-backed securities with prices below 100 is 17.17 percent, while the average for those with prices greater than or equal to 100 is 14.83 percent.

To provide more insight into the heterogeneity in the prepayment risk premia across mortgage-backed securities, it is useful to break down the premium into 
its components. In the following sections, we will examine the turnover and rate response risk premia separately.

\subsection{The Turnover Risk Premium}

As in the previous section, we can identify the turnover risk premium by comparing the implied turnover rate with the empirical turnover rate. The upper panel of Figure 9 plots the time series of the implied turnover rate and the empirical turnover rate.

As illustrated, virtually all of the implied turnover rates are higher than the realized turnover rates. Some of the largest values of the implied turnover rate occur during the first half of 2005. Industry sources suggest that a large fraction of this turnover was motivated by borrowers attempting to "cash out" some of the equity in their homes resulting from the rapid increase in housing values. Thus, the upwards spike in the implied turnover rate during this period may reflect a shift away from the usual interest-rate-related reasons for refinancing towards consumption related incentives for refinancing. The lower panel of Figure 9 plots the turnover risk premium which is computed as the difference between the implied and empirical turnover rates.

The middle panel of Table 8 presents summary statistics for the implied turnover rate, the empirical turnover rate, and the risk premium. The average implied turnover rate is substantially higher than the realized turnover rate. The average implied turnover rate is 17.211 percent, while the average empirical turnover rate is only 3.679. Thus, the average turnover risk premium is 13.532 percent for the sample period. This value is highly statistically significant.

Recall from the previous section that the average prepayment risk premium is 16.015 percent on average. Thus, the average turnover risk premium of 13.532 percent represents 84.50 percent of the entire average prepayment risk, making it by far the primary component. Given the earlier evidence that turnover risk is related to broad trends in the economy, these result suggest that much of the prepayment risk premium in mortgage-backed securities can be linked to the effects of non-interest-rate-related macroeconomic fluctuations on prepayment behavior.

\subsection{The Rate Response Risk Premium}

The upper panel of Figure 10 plots the time series of the implied rate response factor and the empirical rate response factor. As illustrated, the implied and empir- 
ical rate response factors display considerable time series variation and generally track each other closely. Some of the highest values of the rate response factor occur during the 2002-2003 period during which refinancings reached historically high levels. More recent increases in the rate response factor coincide with the rapid expansion of the Home Affordability Refinancing Program (HARP) in which investors with home values below their mortgage balance were allowed to refinance their homes.

The lower panel of Figure 10 shows the rate response risk premium measured as the difference between the implied and empirical rate response factors. Although the risk premium takes both positive and negative values, the time series plot shows that there are generally more negative values than positive values.

The lower panel of Table 8 presents summary statistics for the implied and realized rate response factors along with the risk premium. The average implied rate response factor of 10.432 is slightly lower than the realized rate response factor of 11.907. The average rate response risk premium of -1.475 is relatively small compared to the magnitude of the realized factor, but just crosses the threshold of being statistically different from zero.

The fact that the average rate response risk premium is negative explains why the prepayment risk premia for premium mortgage-backed securities are generally lower than those for discount mortgage-backed security, or are even negative in some cases. Furthermore, the relatively small magnitude of the average rate response risk premium also explains why this risk premium represents only a small portion of the total prepayment risk premium.

\section{CONCLUSION}

We present a new reduced-form framework for modeling the prices of mortgagebacked securities. Rather than imposing an exogenous prepayment function, our approach solves for the actual prepayment function used by the market in pricing mortgage-backed securities. By studying the properties of the implied prepayment function, our goal is to shed light on the key drivers of prepayment risk as perceived by the market.

The evidence suggests that macroeconomic factors play a large role in driving prepayment risk. In particular, we find that prepayment risk can be broken down into three components: interest-rate risk, turnover risk, and rate response risk. We infer the values of the turnover rate and the rate response factors from the data and show that they are strongly related to macroeconomic factors such as consumption, employment, consumer confidenc, and financial market returns. 
Given the strong link between macroeconomic factors and the drivers of implied prepayment risk, our direct evidence that there is a large prepayment risk premium incorporated into the prices of agency mortgage-backed securities makes intuitive sense. What is surprising, however, is that the large majority of the prepayment risk premium appears to be compensation for turnover risk.

We also provide the first direct evidence that mortgage-backed security prices are also driven by changes in the credit risk of the agency guaranteeing the timely payment of principal and interest as well as by changes in the liquidity of the securities. These results are consistent with findings for other markets.

Although there is an extensive literature on the pricing of mortgage-backed securities, previous pricing models have struggled in matching market prices. By their nature, these models generally do not allow for non-interest-rate prepayment factors or risk premia. The differences between model-implied prices and market prices are generally mapped into what is commonly known as the option-adjusted spread. Our results indicate that much of the option-adjusted spread may be explained by allowing for macroeconomic-driven prepayment risk factors and their associated risk premia and by allowing for agency credit risk in the discounting of cash flows. Given the fundamental role of the housing and mortgage-backed security markets in the macroeconomy, our results have many important implications for researchers, policy makers, and practitioners. 


\section{REFERENCES}

Boudoukh, Jacob, Matthew Richardson, Richard Stanton, and Robert F. Whitelaw, 1997, Pricing Mortgage-Backed Securities in a Multifactor Interest Rate Environment: A Multivariate Density Estimation Approach, Review of Financial Studies 10, 405-446.

Boyarchenko, Nina, Andrea Fuster, and David O. Lucca, 2014, Understanding Mortgage Spreads, Federal Reserve Bank of New York Staff Report.

Brennan, Michael J., and Eduardo S. Schwartz, 1985, Determinants of GNMA Mortgage Prices, Real Estate Economics 13, 209-228.

Capone, Charles A., 2001, Introduction to the Special Issue on Mortgage Modeling, Journal of Real Estate Finance and Economics 23, 131-137.

Carlin, Bruce I., Francis A. Longstaff, and Kyle Matoba, 2014, Disagreement and Asset Prices, Journal of Financial Economics 114, 226-238.

Cheyette, Oren, 1996, Implied Prepayments, Journal of Portfolio Management 23, 107-115.

Christensen, Jens, and James M. Gillan, 2015, Does Quantitative Easing Affect Market Liquidity?, Working paper, Federal Reserve Bank of San Francisco.

Christensen, Jens, and Glen D. Rudebusch, 2012, The Response of Interest Rates to U.S. and U.K. Quantitative Easing, Economic Journal 122, F385-F414.

Deng, Yongheng, John M. Quigley, and Robert van Order, 2000, Mortgage Terminations, Heterogeneity and the Exercise of Mortgage Options, Econometrica 68, 275-307.

Downing, Chris, Richard Stanton, and Nancy Wallace, 2005, An Empirical Test of a Two-Factor Mortgage Valuation Model: How Much Do House Prices Matter?, Real Estate Economics 33, 681-710.

Duarte, Jefferson, Francis A. Longstaff, and Fan Yu, 2007, Risk and Return in Fixed-Income Arbitrage: Nickels in Front of a Steamroller?, Review of Financial Studies 20, 769-811.

Duffie, Darrell, and Kenneth J. Singleton, 1997, An Econometric Model of the Term Structure of Interest-Rate Swap Yields, Journal of Finance 52, 1287-1321.

Duffie, Darrell, and Kenneth J. Singleton, 1999, Modeling Term Structures of Defaultable Bonds. Review of Financial Studies 12, 687-720. 
Dunn, Kenneth B., and John J. McConnell, 1981a, A Comparison of Alternative Models for Pricing GNMA Mortgage-Backed Securities, Journal of Finance 36, 471-484.

Dunn, Kenneth B., and John J. McConnell, 1981b, Valuation of GNMA Mortgage-Backed Securities, Journal of Finance 36, 599-616.

Dunn, Kenneth B., and Chester S. Spatt, 2005, The Effect of Refinancing Costs and Market Imperfections on the Optimal Call Strategy and the Pricing of Debt Contracts, Real Estate Economics 33, 595-617.

Fabozzi, Frank J., 2006, The Handbook of Mortgage-Backed Securities, 6th Edition, (ed.), New York, NY: McGraw-Hill.

Gabaix, Xavier, Arvind Krishnamurthy, and Olivier Vigneron, 2007, Limits of Arbitrage: Theory and Evidence from the Mortgage-Backed Securities Market, Journal of Finance 62, 557-595.

Gagnon, Joseph, Matthew Raskin, Julie Remache and Brian Sack, 2011, The Financial Market Effects of the Federal Reserve's Large-Scale Asset Purchases. International Journal of Central Banking 7, 3-43.

Giesecke, Kay, Francis A. Longstaff, Stephen Schaefer and Ilya Strebulaev, 2011, Corporate Bond Default Risk: A 150-Year Perspective, Journal of Financial Economics 102, 233-250.

Goncharov, Yevgeny, 2006, An Intensity-Based Approach to the Valuation of Mortgage Contracts and Computation of the Endogenous Mortgage Rate, International Journal of Theoretical and Applied Finance 9, 889-914.

Gorovoy, Vyacheslav, and Vadim Linetsky, 2007, Intensity-Based Valuation of Residential Mortgages: An Analytically Tractable Model, Mathematical Finance $17,541-573$.

Hanson, Samuel G., 2014, Mortgage Convexity, Journal of Financial Economics 113, 270-299.

Hayre, Lakhbir, 2001, Salomon Smith Barney Guide to Mortgage-Backed and Asset-Backed Securities, John Wiley \& Sons, New York, NY.

Huang, Jing-Zhi and Ming Huang, 2012, How Much of the Corporate-Treasury Yield Spread Is Due to Credit Risk?, Review of Asset Pricing Studies 2, 153-202.

Jarrow, Robert A., David Lando, and Fan Yu, 2005, Default Risk and Diversification: Theory and Empirical Implications, Mathematical Finance 15, 1-26.

Kaelo, P., and M. Ali, 2006, Some Variants of the Controlled Random Search 
Algorithm for Global Optimization, Journal of Optimization Theory and Applications 130, 253-264.

Kau, James B., and Donald C. Keenan, 1995, An Overview of the OptionTheoretic Pricing of Mortgages, Journal of Housing Research 6, 217-244.

Kau, James B., Donald C. Keenan, Walter J. Muller III, and James F. Epperson, 1992, A Generalized Valuation Model for Fixed-Rate Residential Mortgages, Journal of Money, Credit and Banking 24, 279-299.

Kau, James B., and V. Carlos Slawson, Frictions, 2002, Heterogeneity and Optimality in Mortgage Modeling, Journal of Real Estate Finance and Economics 24, 239-260.

Krishnamurthy, Arvind, and Annette Vissing-Jorgensen, 2011, The Effects of Quantitative Easing on Interest Rates: Channels and Implications for Policy, Brookings Papers on Economic Activity, Fall.

Krishnamurthy, Arvind, and Annette Vissing-Jorgensen, 2013, The Ins and Outs of Large Scale Asset Purchases, Kansas City Federal Reserve Symposium on Global Dimensions of Unconventional Monetary Policy.

Levin, Alexander, and Andrew, Davidson, 2005, Prepayment Risk and OptionAdjusted Valuation of MBS, Journal of Portfolio Management 31, 73-85.

Linetsky, Vadim, 2004, The Spectral Decomposition of the Option Value, International Journal of Theoretical and Applied Finance 7, 337-384.

Longstaff, Francis A., 1990, The Valuation of Options on Yields, Journal of Financial Economics 26, 97-121.

Longstaff, Francis A., 2005, Borrower Credit and the Valuation of MortgageBacked Securities, Real Estate Economics 33, 619-661.

Longstaff, Francis A., Sanjay Mithal, and Eric Neis, 2005, Corporate Yield Spreads: Default Risk or Liquidity? New Evidence from the Credit Default Swap Market, Journal of Finance 60, 2213-2253.

Malkhozov, Aytek, Philippe Mueller, Andrea Vedolin, and Gyuri Venter, 2014, Mortgage Risk and the Yield Curve, Working paper, London School of Economics.

Newey, Whitney K, and Kenneth D. West, 1987, A Simple, Positive, SemiDefinite Heteroskedasticity and Autocorrelation Consistent Covariance Matrix, Econometrica 55, 703-708.

Richard, Scott F., and Richard Roll, 1989, Prepayments on Fixed-Rate Mort- 
gage-Backed Securities, Journal of Portfolio Management 15, 73-82.

Schwartz, Eduardo S., and Walter N. Torous, 1989, Prepayment and the Valuation of Mortgage-Backed Securities, Journal of Finance 44, 375-392.

Schwartz, Eduardo S., and Walter N. Torous, 1992, Prepayment, Default, and the Valuation of Mortgage Pass-Through Securities, Journal of Business 65, 221-239.

Schwartz, Eduardo S., and Walter N. Torous, 1993, Mortgage Prepayment and Default Decisions: A Poisson Regression Approach, Real Estate Economics 21, 431-449.

Shao, Anqi, 2012, A Fast and Accurate Simulation for CIR Processes, Ph.D. Thesis, University of Florida.

Song, Zhaogang, and Haoxiang Zhu, 2015, Mortgage Dollar Roll, Working paper, MIT.

Stanton, Richard, 1995, Rational Prepayment and the Valuation of MortgageBacked Securities, Review of Financial Studies 8, 677-708.

Stanton, Richard, and Nancy Wallace, 1998, Mortgage Choice: What's the Point?, Real Estate Economics 26, 173-205.

Titman, Sheridan, and Walter N. Torous, 1989, Valuing Commercial Mortgages: An Empirical Investigation of the Contingent-Claims Approach to Pricing Risky Debt, Journal of Finance 44, 345-373.

Thornton, Daniel L., 2014, QE: Is There a Portfolio Balance Effect?, Federal Reserve Bank of St. Louis Review 96, 55-72.

Vasicek, Oldrich, 1977. An Equilibrium Characterization of the Term Structure, Journal of Financial Economics 5, 177-188.

Vickery, James, and Joshua Wright, 2013, TBA Trading and Liquidity in the Agency MBS Market, Economic Policy Review 19, 1-18.

Wallace, Nancy, 2005, Innovations in Mortgage Modeling: An Introduction, Real Estate Economics 33, 587-593. 


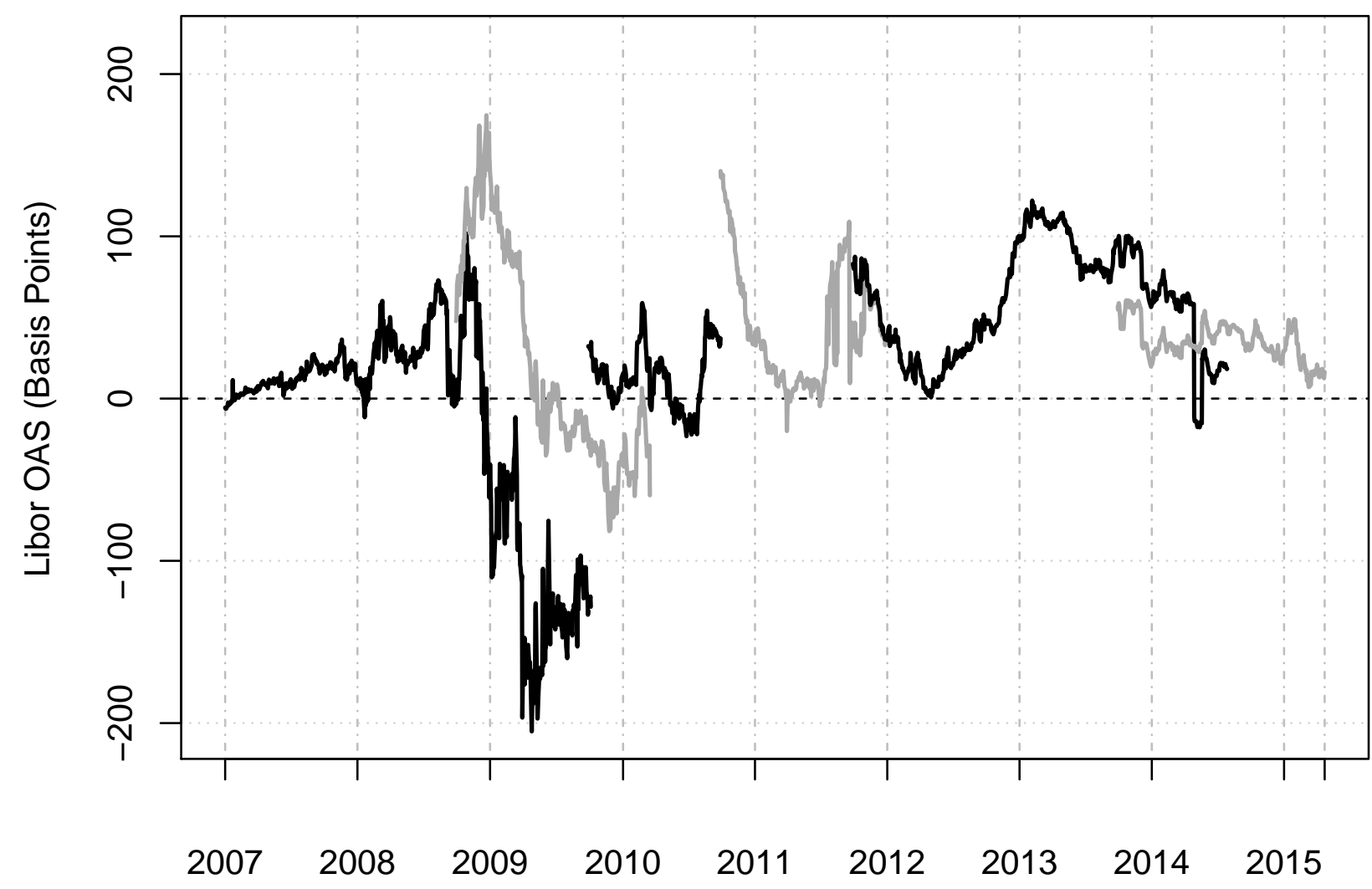

Figure 1. Effects of Prepayment Model Changes on Libor OptionAdjusted Spreads. This figure shows the Libor option-adjusted spread (OAS) in basis points for FNMA 6.50 percent mortgages implied by the series of prepayment models used by a specific major Wall Street dealer. Each line, alternating black and gray, represents a different version of the dealer's prepayment model. During the time period illustrated, the dealer used six different versions of its prepayment model. The Libor option-adjusted spread is highly model dependent, and updates to the prepayment model can lead to large differences in the option-adjusted spread. 


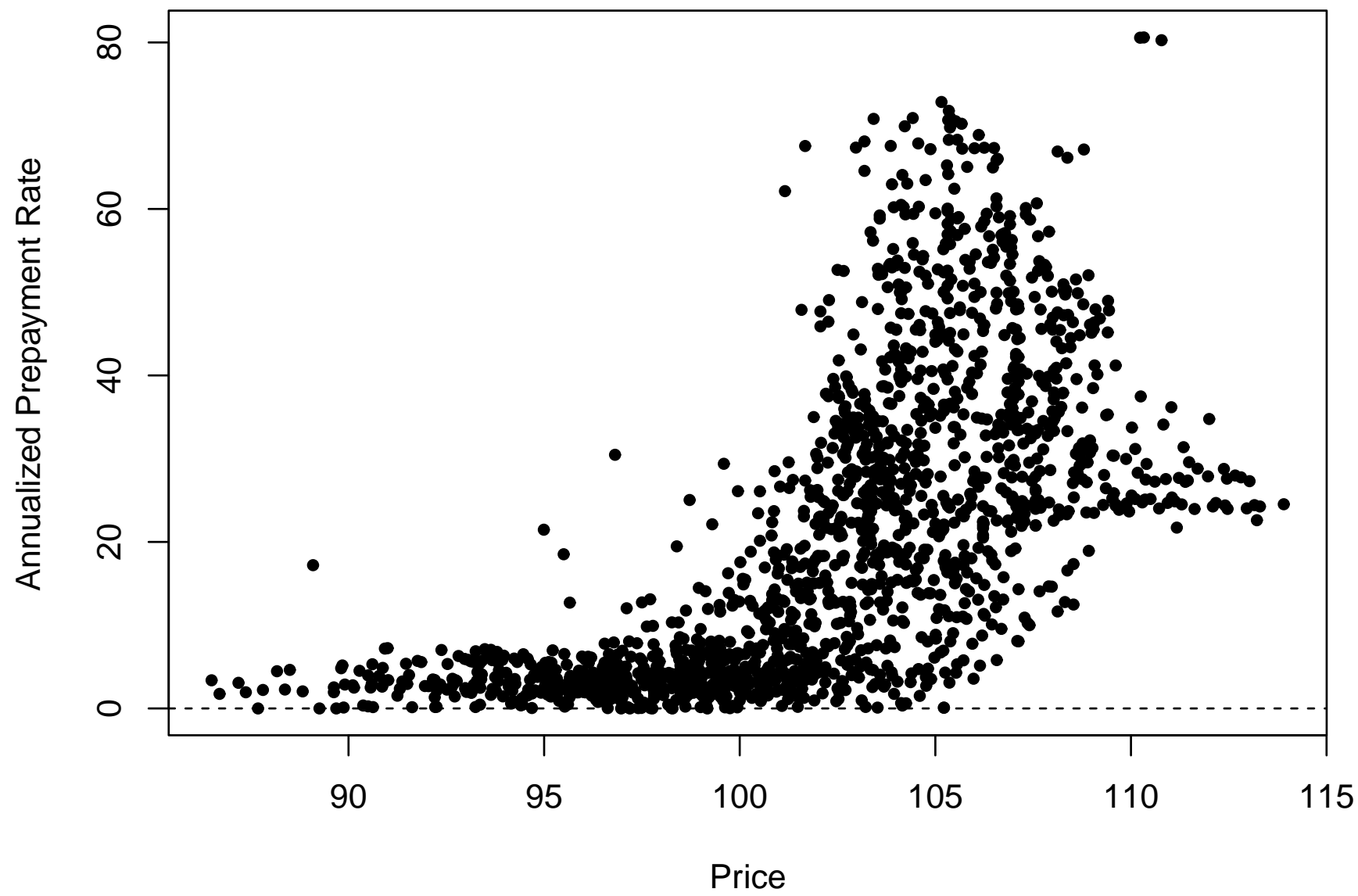

Figure 2. Prepayment Rates for FNMA Mortgage-Backed Securities. This figure plots the three-month prepayment rates for FNMA mortgage-backed securities against the prices of mortgage-backed securities. The prepayment rates are expressed as annualized percentages of the principal balance of the mortgagebacked security. The data consist of monthly observations for all liquid coupons over the January 1998 to September 2014 sample period. 


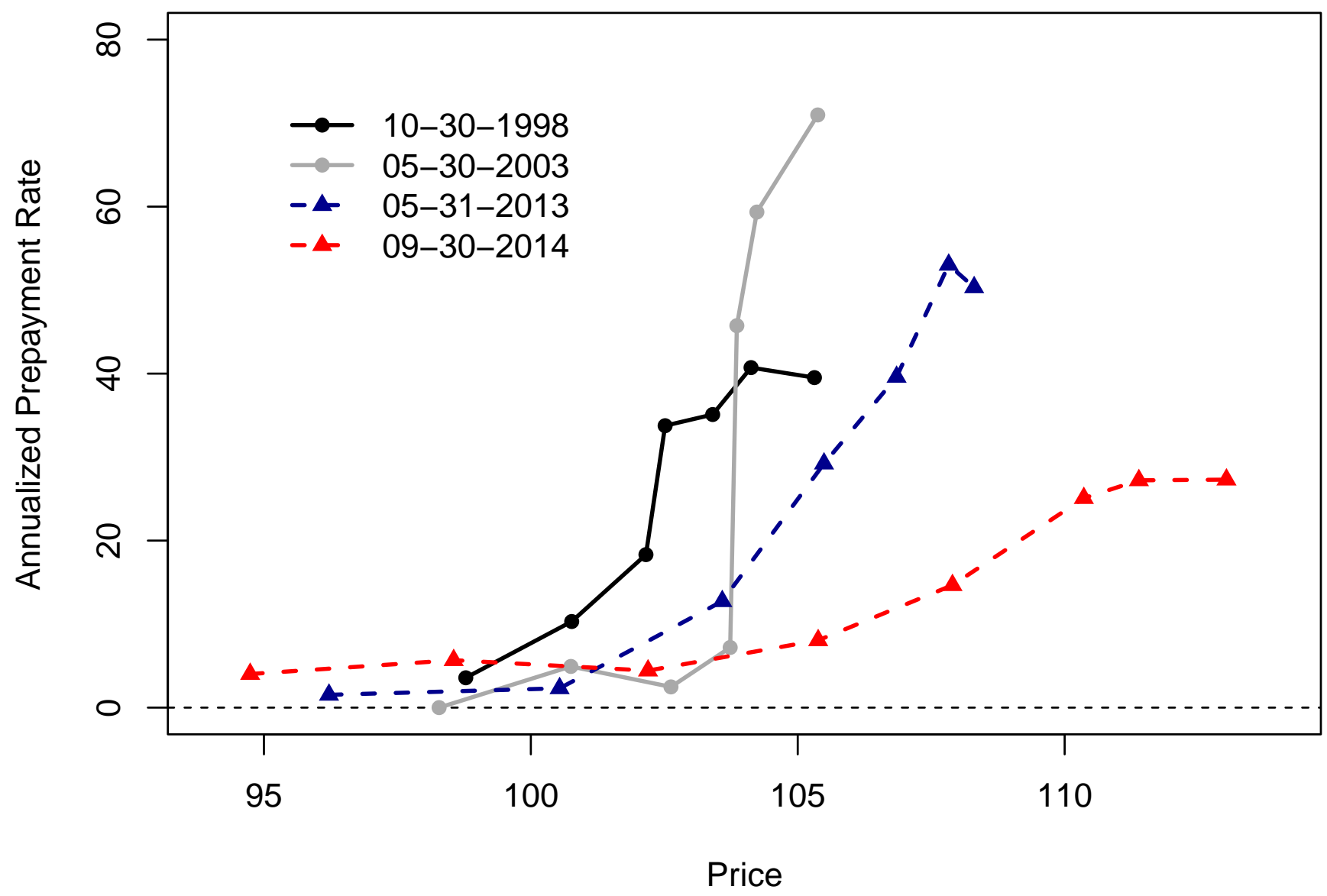

Figure 3. Prepayment Rates for FNMA Mortgage-Backed Securities for Selected Dates. This figure plots the three-month prepayment rates for FNMA mortgage-backed securities against the prices of the mortgage-backed securities for the indicated dates. The prepayment rates are expressed as annualized percentages of the principal balance of the mortgage-backed security. 


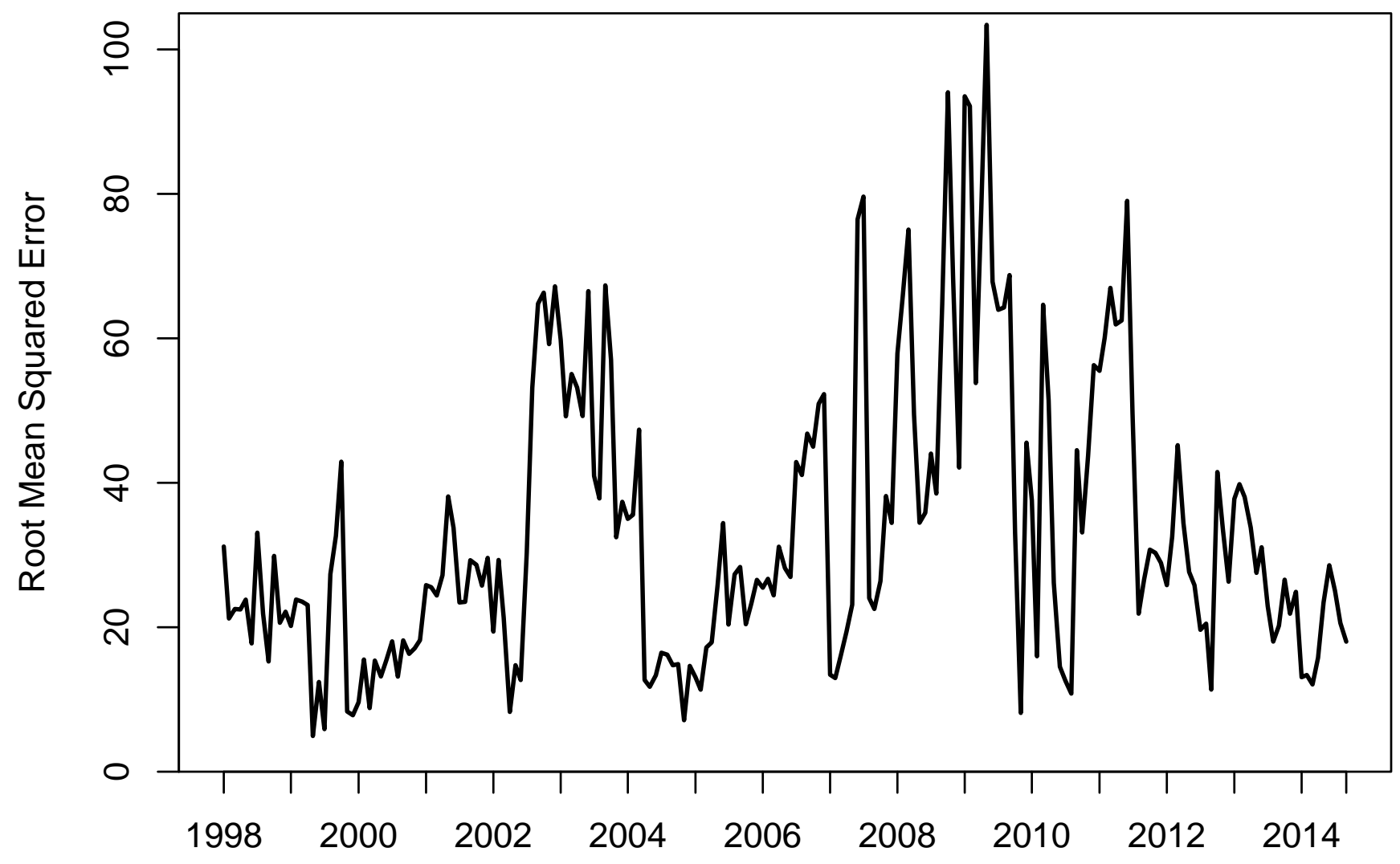

Figure 4. Root Mean Squared Errors from Fitting the Model. This figure plots the time series of root mean squared errors from fitting the model to the cross section of mortgage-backed security prices. The root mean squared error is expressed as cents per $\$ 100$ notional position. 


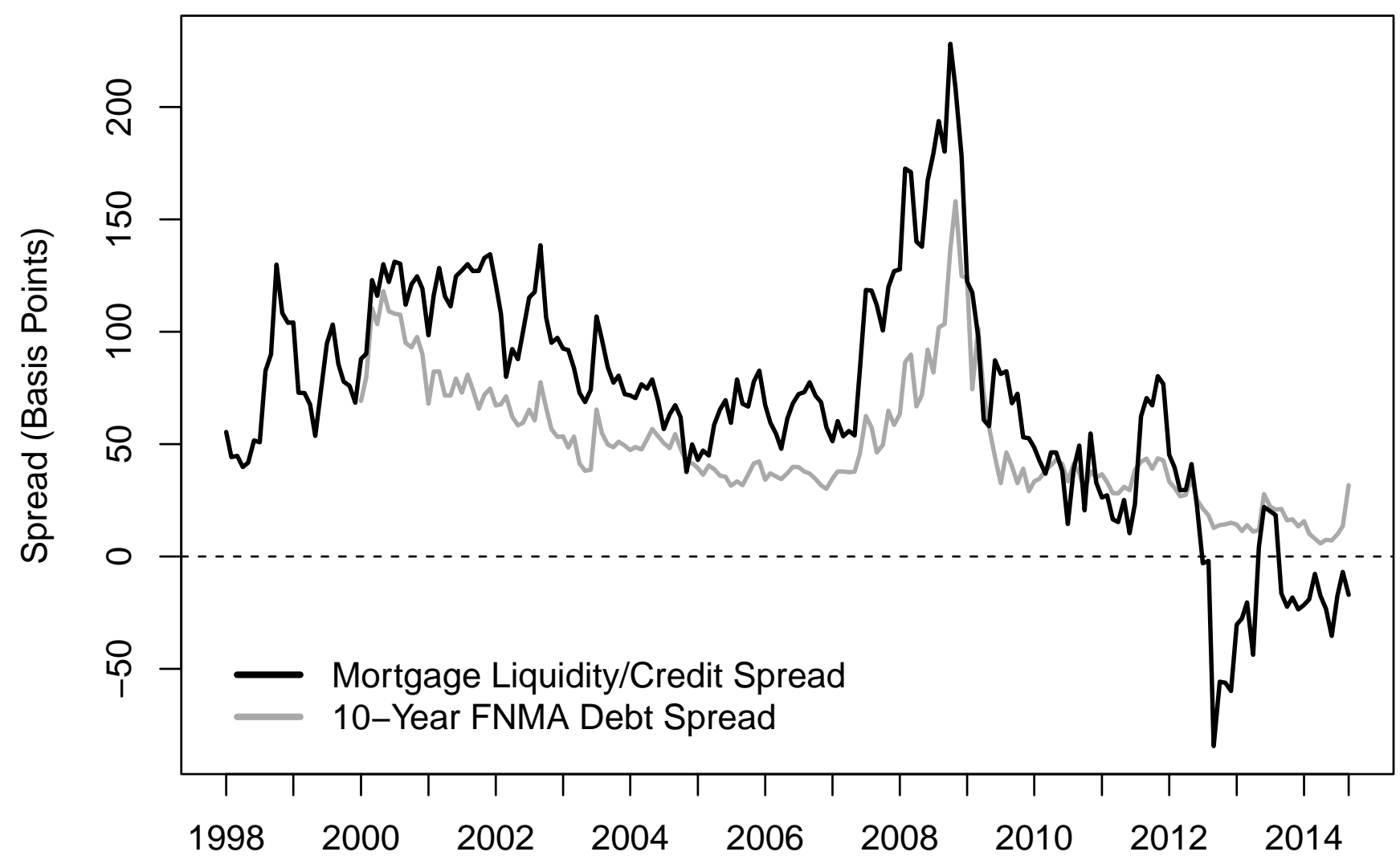

Figure 5. The Implied Credit/Liquidity Spread and the Credit Spread for FNMA Agency Debt. This figure plots the time series of the implied credit/liquidity spread as well as the credit spread for ten-year FNMA agency debt over the ten-year Treasury rate. Both spreads are expressed in basis points. 


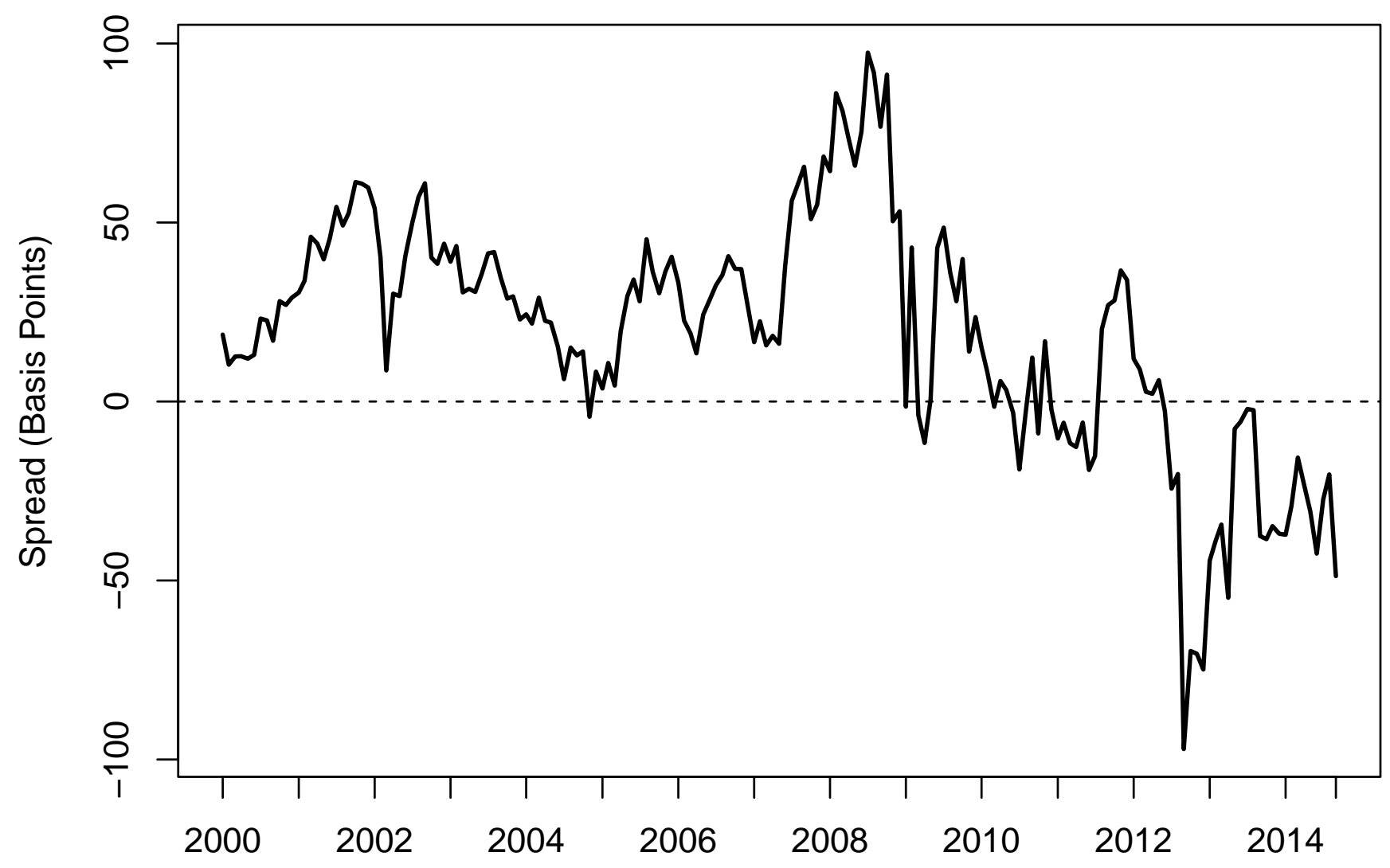

Figure 6. The Estimated Liquidity Spread. This figure plots the time series of the estimated liquidity spread in mortgage-backed securities. The liquidity spread is computed as the difference between the implied credit/liquidity spread and the 10-year FNMA credit spread. The spread is expressed in basis points. 

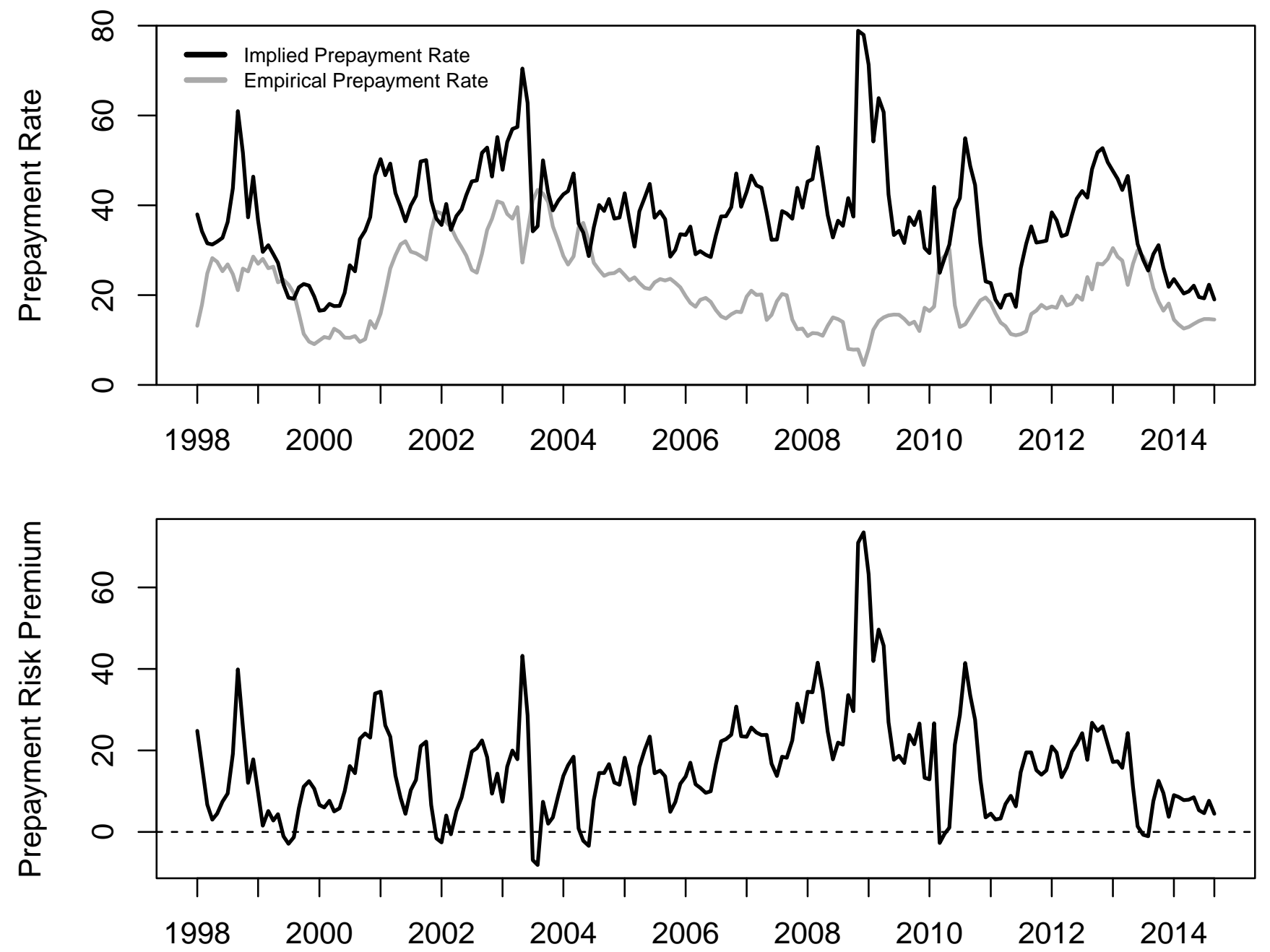

Figure 7. The Implied and Empirical Prepayment Rates and the Prepayment Risk Premium. The upper panel plots the time series of the implied prepayment rate and the empirical prepayment rate (both averaged across all coupon rates for each month). The lower panel plots the time series of the prepayment risk premium defined as the spread between the implied and empirical prepayment rates. The rates and the risk premium are expressed as annualized percentages of the principal balance of the mortgage-backed security. 


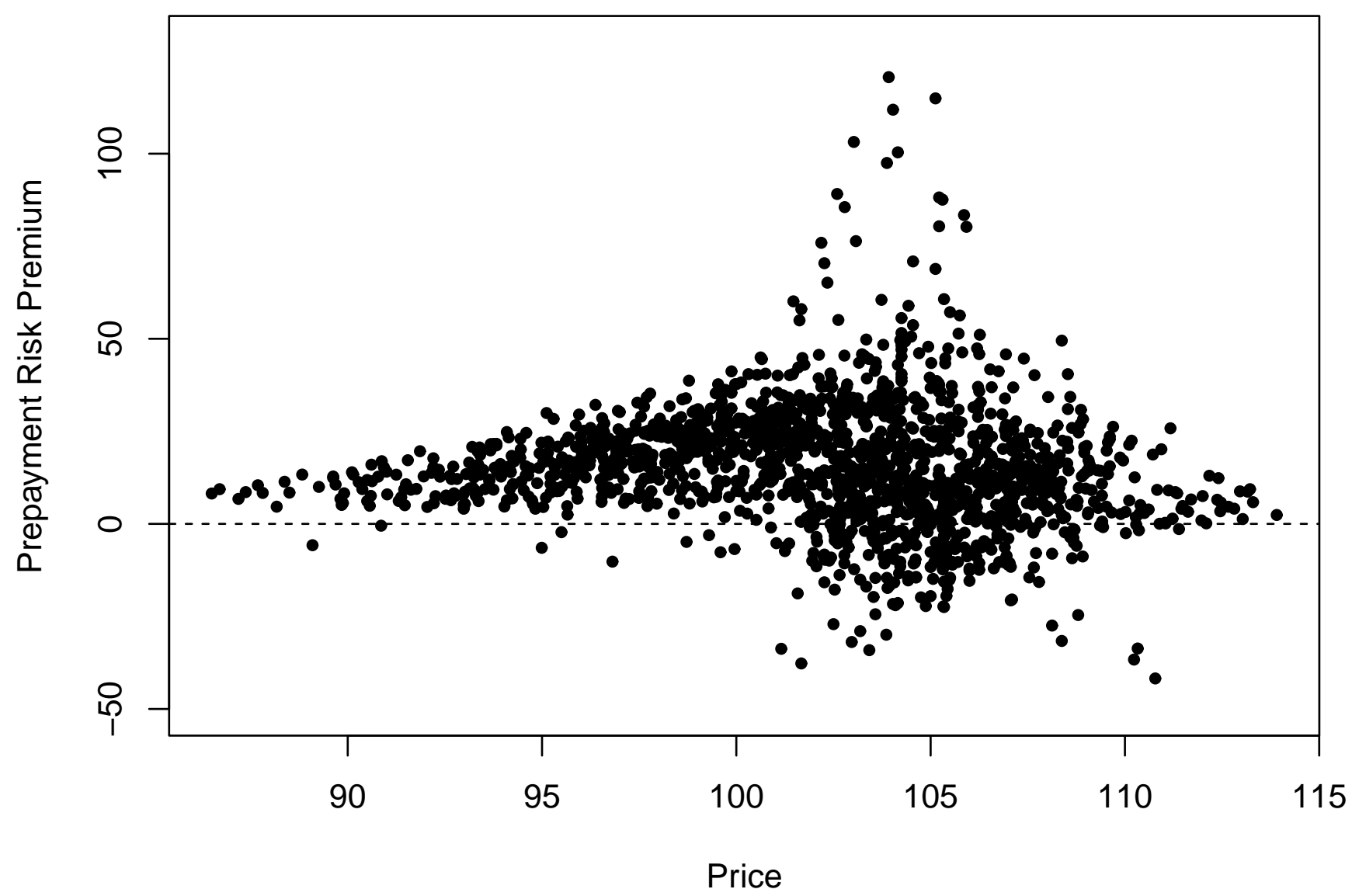

Figure 8. Prepayment Risk Premia. This figure plots the prepayment risk premium for individual mortgage-backed securities as a function of the price of the mortgage-backed security. The risk premia are expressed as annualized percentages of the principal balance of the mortgage-backed security. 

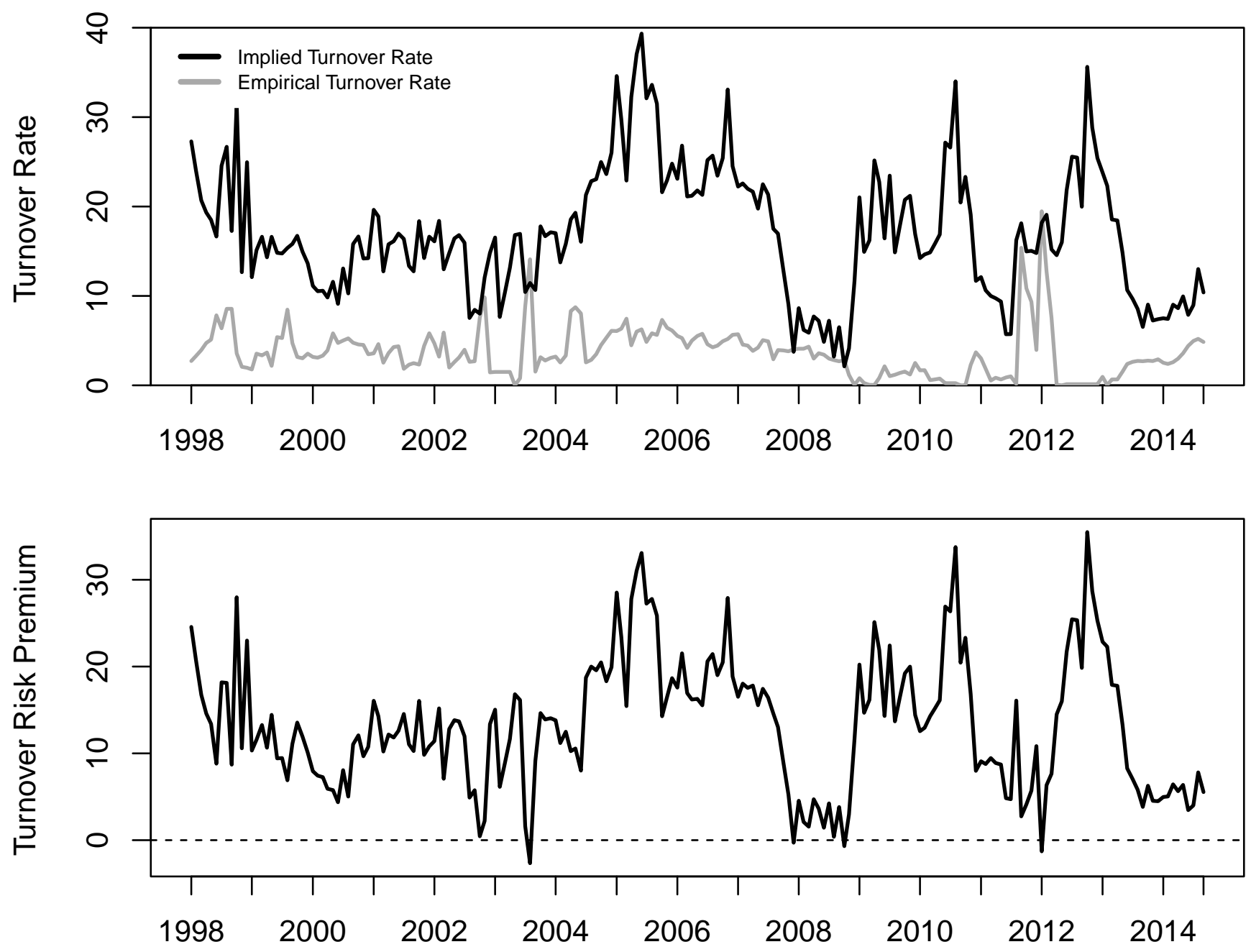

Figure 9. The Implied and Empirical Turnover Rates and the Turnover Risk Premium. The upper panel plots the time series of the implied turnover rate and the empirical turnover rate. The lower panel plots the time series of the turnover risk premium defined as the spread between the implied and empirical turnover rates. The rates and the risk premium are expressed as annualized percentages of the principal balance of the mortgage-backed security. 

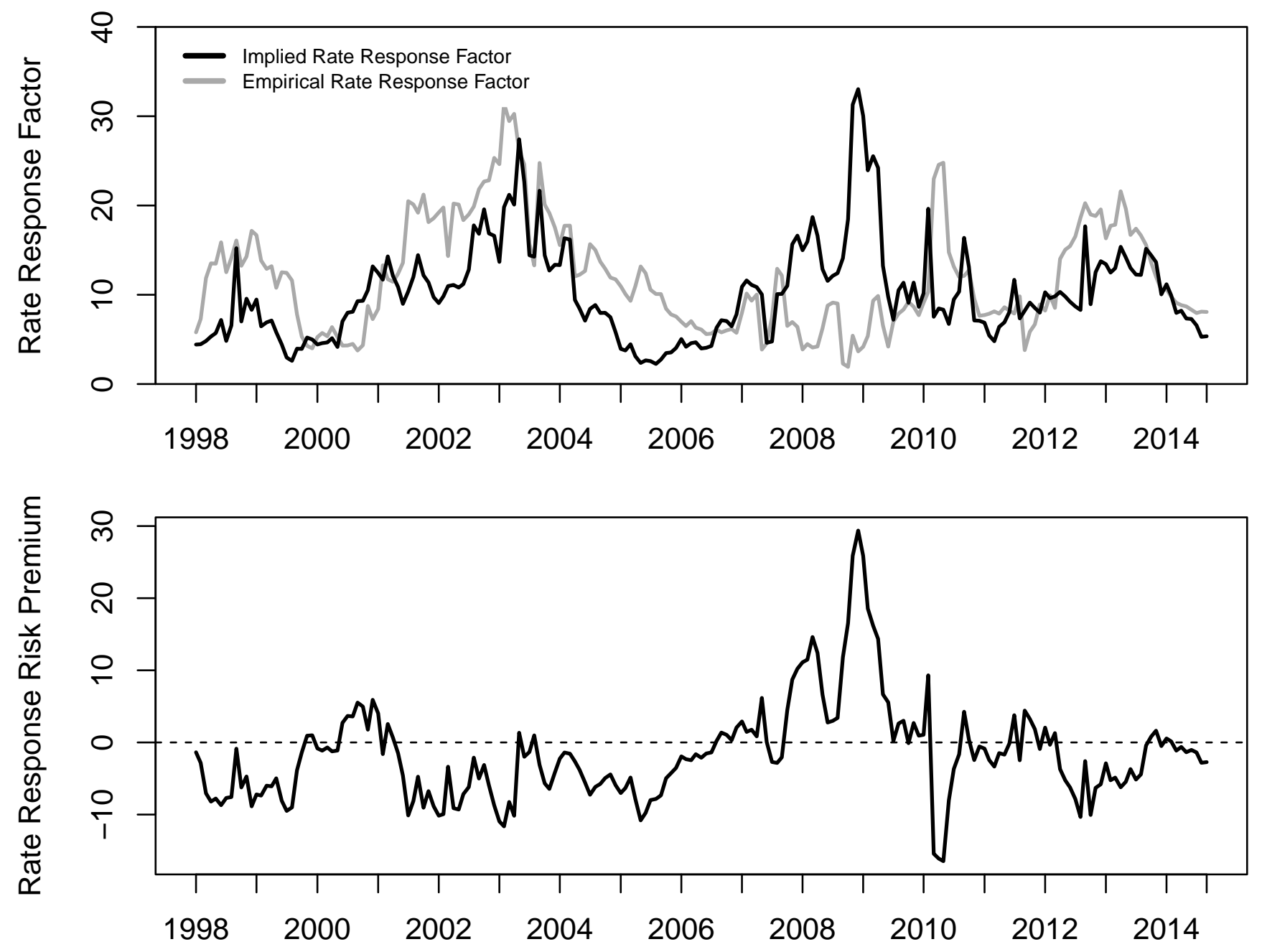

Figure 10. The Implied and Empirical Rate Response Factors and the Rate Response Risk Premium. The upper panel plots the time series of the implied rate response factor and the empirical rate response factor. The lower panel plots the time series of the rate response risk premium defined as the spread between the implied and empirical rate response factors. 
Table 1

Major Events in the Agency Mortgage-Backed Securities Market

2002 Sep-Dec High levels of refinancing activity after Federal Reserve lowers interest rates.

2003 Jan-Jun Refinancing activity continues and reaches historically high levels.

2005 Jan-Jun Mortgage delinquency rates reach historically low levels.

2007 Jun-Jul Two Bear Stearns MBS funds suffer large losses and are liquidated. S\&P places 612 subprime CDOs on creditwatch.

2008 Mar Financially distressed Bear Stearns avoids bankruptcy by being acquired by JP Morgan.

Jul Federal Reserve Bank of New York is authorized to lend to FNMA and FHLMC if need arises.

Sep $\quad$ FNMA and FHLMC are placed into conservatorship, Lehman Brothers defaults.

Dec $\quad$ Federal Reserve announces QE I program to purchase up to $\$ 500$ billion of agency MBS.

2009 Mar Home Affordable Refinance Program and Stability Plan announced, making refinancing easier for high LTV loans.

Mar $\quad$ Federal Reserve expands QE I program to purchase up to an additional $\$ 750$ billion of agency MBS.

Dec Treasury lifts all caps on the amount of FNMA and FHLMC preferred stock it may hold.

2010 Mar QE I purchases of agency MBS ends.

13 Aug FOMC agrees to keep Fed holdings of securities at constant levels by reinvesting cash flows in Treasuries.

14 Nov Federal Reserve announces QE II program to purchase up to $\$ 600$ billion of Treasuries.

152011 Jun QE II purchases of Treasuries ends.

16 Sep Maturity Extension Program "Operation Twist" announced. Agency MBS cash flows to be reinvested in agency MBS.

172012 Sep Federal Reserve announces QE III program, an open-ended program to purchase up to \$40 billion of agency MBS per month.

182013 Jun Ben Bernanke announces "tapering" of QE programs, Dow drops 659 points.

192014 Oct QE III purchases of agency MBS and Treasuries ends.

\section{Sources:}

https://www.stlouisfed.org/financial-crisis/full-timeline.

https://research.stlouisfed.org/publications/review/13/01/Fawley.pdf.

http://www.federalreserve.gov/releases/chargeoff/delallsa.htm. 
Table 2

Summary Statistics for FNMA Mortgage-Backed Securities. This table reports summary statistics for FNMA mortgage-backed securities with the indicated coupon rates. Average Moneyness denotes the average difference between the coupon rate and the current coupon mortgage rate. Average CPR denotes the average three month constant proportional repayment rate. $N$ denotes the number of observations.

The sample consists of monthly observations for the period from January 1998 to September 2014.

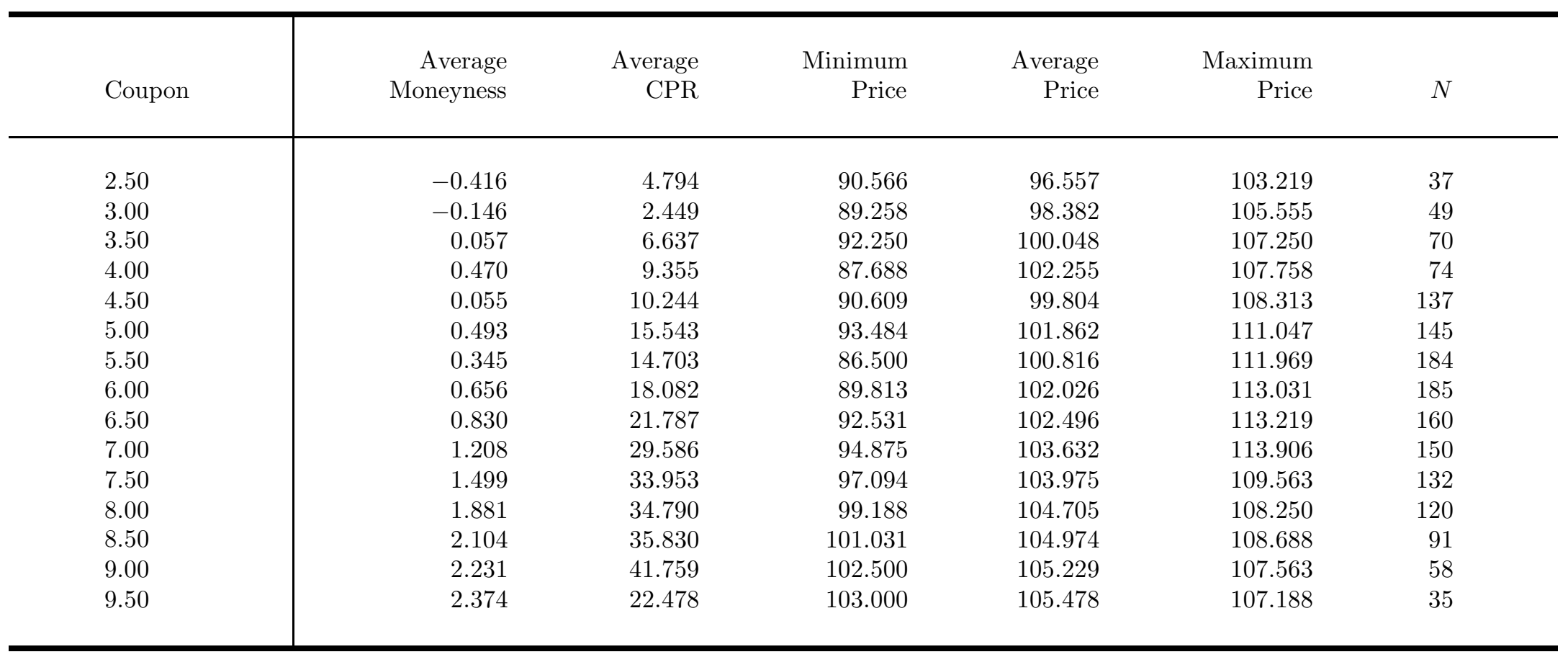


Table 3

Estimates of Model Parameters. This table reports the estimate of the model parameters along with their asymptotic standard errors.

\begin{tabular}{lcc}
\hline Parameter & Value & Std. Error \\
& & \\
\hline & & \\
$b$ & 0.00837 & 0.00151 \\
$\alpha_{w}$ & 0.90582 & 0.01256 \\
$\alpha_{x}$ & 0.00196 & 0.00075 \\
$\alpha_{y}$ & 0.01653 & 0.00094 \\
$\beta_{w}$ & 0.02865 & 0.05145 \\
$\beta_{x}$ & 0.09795 & 0.01135 \\
$\beta_{y}$ & 0.30509 & 0.00903 \\
$\sigma_{w}$ & 0.02710 & 0.02357 \\
$\sigma_{x}$ & 0.00036 & 0.03092 \\
$\sigma_{y}$ & 0.01694 & 0.00629 \\
& 0.07360 & 0.04235 \\
\hline
\end{tabular}


Table 4

Summary Statistics for the Mortgage-Backed Security Pricing Factors. This table reports summary statistics for the agency credit/liquidity spread (Spread), the turnover rate (Turnover), and the rate response factor (Response). Spread is expressed in basis points. Turnover is expressed as a percentage. The factors are estimated from the cross section of mortgage-backed security prices. The sample consists of monthly observations for the period from January 1998 to September 2014.

\begin{tabular}{|c|c|c|c|}
\hline Statistic & Spread & Turnover & Response \\
\hline Mean & 72.092 & 17.211 & 10.432 \\
\hline Minimum & -85.151 & 2.123 & 2.253 \\
\hline Median & 70.471 & 16.430 & 9.479 \\
\hline Maximum & 228.117 & 39.343 & 33.032 \\
\hline Standard Deviation & 52.213 & 7.173 & 5.518 \\
\hline Serial Correlation & 0.947 & 0.799 & 0.851 \\
\hline Number & 201 & 201 & 201 \\
\hline
\end{tabular}


Table 5

Results from the Regression of Monthly Changes in the Implied Credit/Liquidity Spread on Explanatory Variables. This table reports the results from the regression of the monthly change in the implied credit/liquidity spread (measured in basis points) on its lagged value, the change in the FNMA credit spread (measured in basis points), the contemporaneous and lagged change in primary dealers' holdings of mortgage-backed securities (measured in $\$$ millions), the change in the general collateral repo rate (measured in basis points), net issuance of mortgage-backed securities (measured in millions), and the ratio of Federal Reserve purchases of mortgage-backed securities to net issuance of mortgage-backed securities. All changes are monthly. The $t$-statistics are based on the Newey-West (1987) estimator of the covariance matrix (with four lags). The superscript ${ }^{* *}$ denotes significance at the five-percent level; the superscript ${ }^{*}$ denotes significance at the ten-percent level. The sample period is January 2000 to September 2014.

Variable

Intercept

Lagged Change in Implied Spread

Change in FNMA Spread

Change in Dealer Inventories

Lagged Change in Dealer Inventories

Change in Repo Rate

Net MBS Issuance

Ratio of Fed Purchases to Net MBS Issuance

Adj. $R^{2}$

$N$

\section{Coefficient $\quad t$-Statistic}

$\begin{array}{rc}0.27457 & 0.23 \\ -0.01131 & -0.14 \\ 0.83522 & 9.12^{* *} \\ -0.00018 & -1.22 \\ -0.00022 & -2.00^{* *} \\ -5.28683 & -1.55 \\ -0.00004 & -1.00 \\ 0.04702 & 2.46^{* *}\end{array}$

0.2441 
Table 6

Results from the Regression of Quarterly Changes in the Empirical and Implied Turnover Rates on Explanatory Variables. This table reports the results from regressions of the quarterly change in the turnover rate on its lagged value, the change in the mortgage foreclosure rate the lagged change in the mortgage delinquency rate, the lagged growth rate in personal consumption expenditures, the change in US unemployment rate, the return on the Barclays US aggregate bond index, the lagged CRSP value-weighted stock index return, the change in the cash-out mortgage activity index, and the lagged change in the US Home Builders Housing Index. The center panel presents the results for the regression in which the change in the empirical rate response factors is the dependent variable. The right panel presents the results for the regression in which the change in the implied rate response factor is the dependent variable. All variables are measured quarterly. The t-statistics are based on the Newey-West (1987) estimator of the covariance matrix (with three lags). The superscript ${ }^{* *}$ denotes significance at the five-percent level; the superscript ${ }^{*}$ denotes significance at the ten-percent level. The sample period is January 1998 to September 2014.

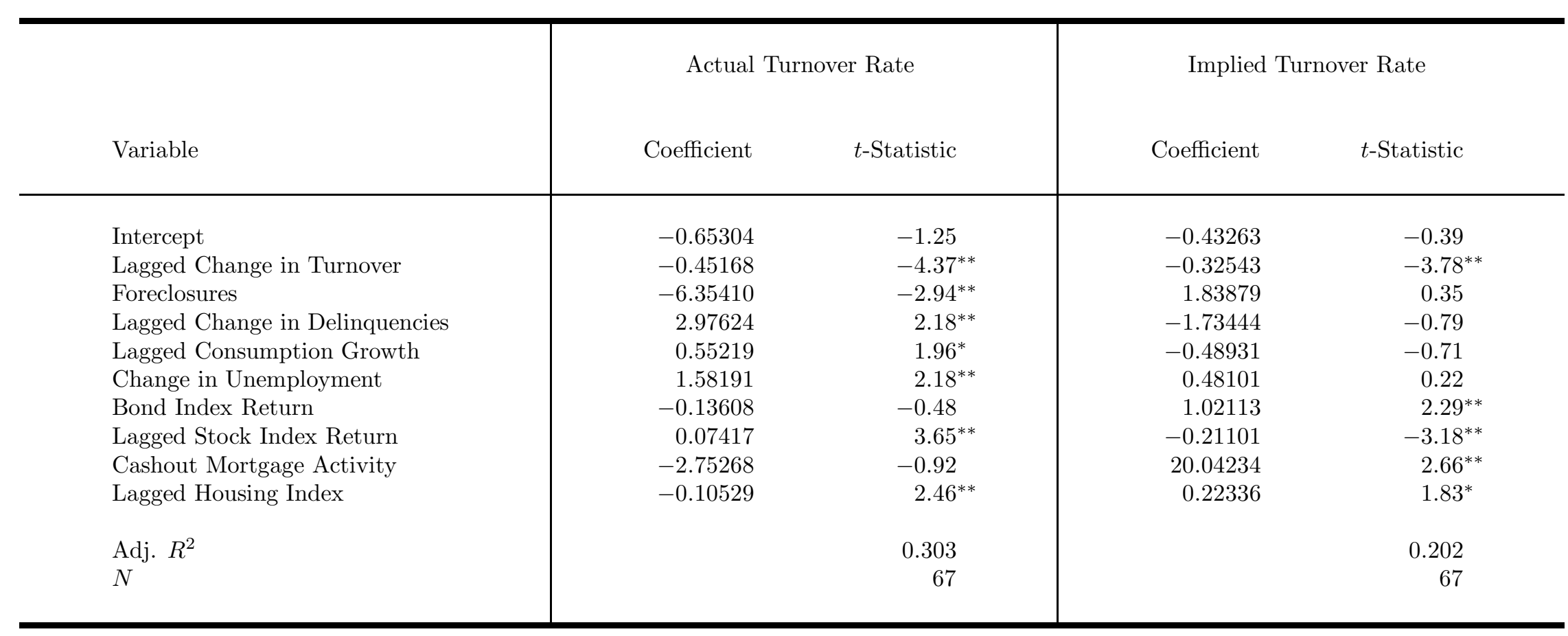


Results from the Regression of Quarterly Changes in the Empirical and Implied Rate Response on Explanatory Variables. This table reports the results from the regression of the quarterly change in the turnover rate on its lagged value, the change in the bank credit tightening index, the change in the FHLMC loan-to-value ratio for all conventional mortgages, the change in aggregate consumer credit, the lagged growth rate in personal consumption expenditures, the change in the Conference Board consumer confidence index, the change in the US unemployment rate, the return on the Barclays US aggregate bond index, the lagged CRSP value-weighted stock index return, and the lagged change in the US Home Builders Market Index. The center panel presents the results for the regression in which the change in the empirical rate response factors is the dependent variable. The right panel presents the results for the regression in which the change in the implied rate response factor is the dependent variable. All variables are measured quarterly. The $t$-statistics are based on the Newey-West (1987) estimator of the covariance matrix (with three lags). The superscript ${ }^{* *}$ denotes significance at the five-percent level; the superscript ${ }^{*}$ denotes significance at the ten-percent level. The sample period is January 1998 to September 2014.

\begin{tabular}{|c|c|c|c|c|}
\hline \multirow[b]{2}{*}{ Variable } & \multicolumn{2}{|c|}{ Actual Rate Response } & \multicolumn{2}{|c|}{ Implied Rate Response } \\
\hline & Coefficient & $t$-Statistic & Coefficient & $t$-Statistic \\
\hline Intercept & 2.14403 & 1.32 & -2.84239 & $-1.80^{*}$ \\
\hline Lagged Change in Rate Response & -0.19025 & $-1.74^{*}$ & -0.08544 & -0.76 \\
\hline Credit Tightening & -0.04499 & -1.51 & 0.02277 & 0.51 \\
\hline Change in Loan-to-Value Ratio & -0.56175 & -0.40 & -0.46346 & -0.85 \\
\hline Change in Consumer Credit & -0.01208 & -1.63 & 0.00114 & 0.05 \\
\hline Lagged Consumption Growth & -1.95335 & $-3.24^{* *}$ & 0.63379 & 0.75 \\
\hline Change in Consumer Confidence & -0.12507 & $-2.58^{* *}$ & -0.14176 & $-1.97^{*}$ \\
\hline Change in Unemployment & -0.83600 & -0.35 & -2.48097 & -1.21 \\
\hline Bond Index Return & 0.34944 & 1.46 & 1.30102 & $3.79^{* *}$ \\
\hline Lagged Stock Index Return & -0.01787 & -0.34 & 0.03545 & 0.49 \\
\hline Lagged Housing Index & -0.05454 & -0.81 & -0.19088 & $-3.62^{* *}$ \\
\hline Adj. $R^{2}$ & & 0.242 & & 0.489 \\
\hline$N$ & & 67 & & 67 \\
\hline
\end{tabular}




\section{Table 8}

Summary Statistics for Actual and Implied Prepayment Rates, Turnover Rates, and Rate Response Factors. This table reports summary statistics for the indicated variables. The prepayment rates are computed as averages taken over all mortgage-backed securities each month. Prepayment rates and turnover rates are expressed as percentages. Ratio denotes the actual value divided by the implied value. The sample consists of monthly observations for the period from January 1998 to September 2014.

\begin{tabular}{|c|c|c|c|c|c|c|}
\hline & Average & $\begin{array}{l}\text { Standard } \\
\text { Deviation }\end{array}$ & Minimum & Median & Maximum & $N$ \\
\hline $\begin{array}{l}\text { Implied Prepayment Rate } \\
\text { Actual Prepayment Rate } \\
\text { Difference }\end{array}$ & $\begin{array}{l}37.257 \\
21.241 \\
16.015\end{array}$ & $\begin{array}{r}11.493 \\
8.395 \\
12.464\end{array}$ & $\begin{array}{r}16.526 \\
4.443 \\
-8.104\end{array}$ & $\begin{array}{l}37.239 \\
19.777 \\
14.471\end{array}$ & $\begin{array}{l}78.869 \\
43.438 \\
73.515\end{array}$ & $\begin{array}{l}201 \\
201 \\
201\end{array}$ \\
\hline $\begin{array}{l}\text { Implied Turnover Rate } \\
\text { Actual Turnover Rate } \\
\text { Difference }\end{array}$ & $\begin{array}{r}17.211 \\
3.679 \\
13.532\end{array}$ & $\begin{array}{l}7.173 \\
2.832 \\
7.496\end{array}$ & $\begin{array}{r}2.123 \\
0.000 \\
-2.653\end{array}$ & $\begin{array}{r}16.430 \\
3.320 \\
13.268\end{array}$ & $\begin{array}{l}39.343 \\
19.470 \\
35.491\end{array}$ & $\begin{array}{l}201 \\
201 \\
201\end{array}$ \\
\hline $\begin{array}{l}\text { Implied Rate Response } \\
\text { Actual Rate Response } \\
\text { Difference }\end{array}$ & $\begin{array}{r}10.432 \\
11.907 \\
-1.475\end{array}$ & $\begin{array}{l}5.518 \\
6.043 \\
6.823\end{array}$ & $\begin{array}{r}2.253 \\
1.921 \\
-16.462\end{array}$ & $\begin{array}{r}9.479 \\
10.562 \\
-2.107\end{array}$ & $\begin{array}{l}33.032 \\
31.445 \\
29.375\end{array}$ & $\begin{array}{l}201 \\
201 \\
201\end{array}$ \\
\hline
\end{tabular}




\section{Appendix}

In this appendix, we first describe the variables used in the study along with the sources for the data. We then describe the methodology used in the estimation of the model.

\section{A.1 Data Sources}

Table A1 presents the definitions and data sources for the variables used in the study.

\section{A.2 Fannie Mae Mortgage-Backed Security Cash Flows}

The pricing data are from the to-be-announced (TBA) market for 30-year Fannie Mae (FNMA) mortgage-backed securities (MBS). Before describing how we estimate our model, it is important to consider the timing of cash flows generated by a FNMA TBA trade.

TBA trades settle according to a monthly schedule set by the Securities Industry and Financial Markets Association (SIFMA). Thirty-year FNMA MBS falls into SIFMA's Class A, which typically settles during the second week of the month. Because we select prices at the end of each month, the settlement date corresponding to these observations is around the second week of the following month (the exact settlement dates can be found on Bloomberg). On the notification date, two days prior to settlement, the buyer is notified of the exact pools to be delivered. On the settlement date, the buyer transfers a payment to the seller, which consists of the agreed upon price (which we observe at month end) plus accrued interest on the exact face value of the pools identified on the notification date. On the record date, the last day of the month, Fedwire records the buyer as the new holder of the security. On the fifth or sixth business day of the next month, the pool factors (current balance / original balance) are released. The pool factor determines the new face value of the mortgage after accounting for scheduled principal payments and prepayments from the previous month. Then, on the payment date later that month, the scheduled principal payments, interest payments, and prepayments, less servicing and guaranty fees are passed to the holder of the security. For FNMA MBS, the payment date is the 25th of the month. If the 25th day happens to fall on a bond market holiday or a weekend, the payment is made on the following business day. A timeline for the timing of payments for a hypothetical TBA trade is shown in Table A2.

\section{A.3 Adjustment for Fees}

Fixed-rate mortgage pools consist entirely of fixed-rate loans, but the underlying loans may bear different fixed rates of interest. Interest on a fixed-rate pool is set on the issue date of the related certificates and it is equal to the interest 
rates less the fee percentages for each loan in the pool. The fee percentage is the sum of the servicing fee and the guaranty fee for that loan. Fixed-rate loans in a single pool have interest rates that are within a two percent range (sometimes a wider range may be allowed). However, the pass-through rate of each loan in fixed rate pool is the same. Therefore, the pass-through rate will not change if prepayments occur.

Consider the cash flow generated by a pass-through of an individual fixed rate mortgage. Prior to either prepayment or default, the owner of the pass-through receives the constant cash flow $c$ generated by the mortgage loan less the servicing and guaranty fees, which are a percentage of the principal balance $I_{t}$. Denote the servicing and guaranty fees by the constant $g$. Then, the cash flow generated by the pass-through security, $c_{t}^{P T}$, in absence of prepayment, is

$$
c_{t}^{P T}=c-g I_{t}
$$

Therefore, the value of a FNMA MBS, after accounting for fees, is given by

$$
F(m, T)=E^{Q}\left[\int_{0}^{T} \exp \left(-\int_{0}^{t} r_{s}+w_{s} d s\right) N_{t}\left(c+\left(p_{t}-g\right) I_{t}\right) d t\right],
$$

where

$$
p_{t}=x_{t}+y_{t} \max \left(0, m-a-b r_{t}\right) \text {. }
$$

\section{A.4 Valuation}

Due to the independence of $w_{t}$ from the other stochastic processes, we can write

$$
F(m, T)=\int_{0}^{T} S(t) E^{Q}\left[\exp \left(-\int_{0}^{t} r_{s} d s\right) N_{t}\left(c+\left(p_{t}-g\right) I_{t}\right)\right] d t
$$

where

$$
S(t)=E^{Q}\left[\exp \left(-\int_{0}^{t} w_{s} d s\right)\right] .
$$

The expression for $S(t)$ is given by

$$
S(t)=A(t) \exp \left(-w_{0} B(t)\right)
$$


where

$$
\begin{aligned}
A(t) & =\exp \left(\left(\frac{\sigma_{w}^{2}}{2}-\frac{\alpha_{w}}{\beta_{w}}\right) t+\left(\frac{\alpha_{w}}{\beta_{w}^{2}}-\frac{\sigma_{w}^{2}}{\beta_{w}^{3}}\right)\left(1-\exp \left(-\beta_{w} t\right)\right)\right. \\
& \left.+\frac{\sigma_{w}^{2}}{4 \beta^{3}}\left(1-\exp \left(-\beta_{w} t\right)\right)\right) \\
B(t) & =\frac{1}{\beta_{w}}\left(1-\exp \left(-\beta_{w} t\right)\right) .
\end{aligned}
$$

Applying the separation theorem of Longstaff (1990), we can bring the discount factor out of the expectation. Hence,

$$
F(m, T)=\int_{0}^{T} S(t) D(t) \hat{E}\left[N_{t}\left(c+\left(p_{t}-g\right) I_{t}\right)\right] d t
$$

where $D(t)$ is the price of a zero-coupon bond and the expectation $\hat{E}[\cdot]$ is taken with respect to the forward measure.

\section{A.5 Adjustments For Discrete Cash Flows}

In this section, we adjust the mortgage valuation formula to account for the actual cash flows from a TBA trade. Let

$$
\tilde{T} \equiv\left\{0, t_{s}, t_{1}, \ldots, t_{K}\right\}
$$

be the set of points in time related to the payments associated with a mortgagebacked security with $K$ months until maturity. The valuation date, or trade date, is $t=0$. The MBS settles at $t=t_{s}$, and the MBS investor receives payments on dates $t_{1}$ through $t_{K}$. Since the settlement dates are fixed by SIFMA, the amount of time from the valuation date $t=0$ through the settlement date $t=t_{s}$ varies depending on the trade date. Also, due to holidays and weekends, each time step after settlement, i.e. $\Delta t_{i} \equiv t_{i+1}-t_{i}, i=1, \ldots, K-1$, may vary by a couple of days. Let $\mathrm{CF}_{i}$ be the cash flow received by the mortgage investor at time $t_{i}$. In our framework, the value of the mortgage is

$$
F(m, K)=\frac{1}{S\left(t_{s}\right) D\left(t_{s}\right)} \sum_{i=1}^{K} S\left(t_{i}\right) D\left(t_{i}\right) \hat{E}\left[\mathrm{CF}_{i}\right]
$$

To determine the cash flow $\mathrm{CF}_{i}$ at $t_{i}$, we can apply standard mortgage cash flow formulas (recall that in continuous time, the cash flow is $N_{t}\left[c+\left(p_{t}-g\right) I_{t}\right]$ ). Following Hayre (2001), for each dollar of a mortgage in month $i$, 


$$
\begin{aligned}
\text { Monthly payment } & =\mathrm{PAY}_{i}=\frac{m / 12}{1-(1+m / 12)^{-K}}, \\
\text { Balance }(\text { end of month }) & =\mathrm{BAL}_{i}=\frac{1-(1+m / 12)^{-K+i}}{1-(1+m / 12)^{-K}}, \\
\text { Principal portion of payment } & =\mathrm{PRIN}_{i}=\mathrm{PAY}_{i} \times(1+m / 12)^{-K-1+i}, \\
\text { Interest portion of payment } & =\mathrm{INT}_{i}=\mathrm{PAY}_{i}-\mathrm{PRIN}_{i} .
\end{aligned}
$$

Let

$$
\tilde{T}_{C F} \equiv\left\{0, \tau_{1}, \ldots, \tau_{K}\right\}
$$

be the set of points in time relevant to determine the monthly cash flows of the MBS. This set corresponds to month-ends. For the example in Table A2, $t=0$ is March 31st, the month end before the settlement date, and $\tau_{1}$ is April 30th. Note that it is possible that $\tau_{1}$ is either before or after the trade date depending on whether the trade date and settlement date occur in the same month. However, because the data are observed at each month end, the elements of $\tilde{T}$ and $\tilde{T}_{C F}$ are ordered as

$$
0<t_{s}<\tau_{1}<t_{1}<\tau_{2}<t_{2}<\cdots<\tau_{K}<t_{K}
$$

as shown in the example in Table A2.

Recall that $N_{t}$ represents the fraction of the mortgage pool that has not yet prepaid (i.e. a survival factor). To keep track of monthly prepayments, we calculate the single monthly mortality (SMM), a common object in mortgage modeling. SMM is fraction of the pool outstanding at the beginning of the month that is prepaid during the month. Hence,

$$
\mathrm{SMM}_{i}=\frac{N_{\tau_{i-1}}-N_{\tau_{i}}}{N_{\tau_{i-1}}}
$$

Therefore, the prepayments in a given month $i, \mathrm{PP}_{i}$, can be written as

$$
\mathrm{PP}_{i}=\left(\mathrm{BAL}_{i-1} \times N_{\tau_{i-1}}-\mathrm{PRIN}_{i} \times N_{\tau_{i-1}}\right) \times \mathrm{SSM}_{i}
$$

Note that the cash flow $\mathrm{CF}_{i}$ received by the investor at $t_{i}$ reflects the payments (scheduled and prepaid) at $\tau_{i}$ from the underlying mortgage loans, less servicing and guaranty fees $g$. Therefore, 


$$
\mathrm{CF}_{i}=\mathrm{PRIN}_{i} \times N_{\tau_{i-1}}+\mathrm{PP}_{i}+\frac{m-g}{m} \times \mathrm{INT}_{i} \times N_{\tau_{i-1}} .
$$

Given paths of $r_{t}, x_{t}$, and $y_{t}$, we calculate a path of $p_{t}$. After integration and exponentiation, we calculate $N_{t}$ for the relevant time points. Then, the standard mortgage formulas provide the cash flows.

\section{A.6 The Discount Function}

We collect historical data on nominal-constant maturity Treasury rates from the Federal Reserve's H.15 statistical release. Then, we use a standard cubic spline to bootstrap the prices of zero-coupon bonds $D(t)$ for the relevant time points for up to 30 years. For a discussion of this methodology, see Longstaff, Mithal, and Neis (2005).

\section{A.7 Estimation of Interest Rate Dynamics}

We assume that the interest rate follows the Ornstein-Uhlenbeck process

$$
d r_{t}=\left(\alpha_{r}-\beta_{r} r_{t}\right) d t+\sigma_{r} d Z_{r}
$$

Mortgage rates are most closely related to the 10 -year rate. Therefore, we fit the 10-year zero-coupon rate exactly. From the time series of $D(10)$, we estimate $\alpha_{r}$, $\beta_{r}$, and $\sigma_{r}$ via conditional maximum likelihood. Note that this provides us with parameters under the real-world probability measure. However, the refinance incentive $\max (0, m-a-b r)$ involves an affine function of $r$. Therefore, when we estimate $a$ and $b$ later in the procedure, we are effectively allowing for a constant risk premium.

Conditional on $r(s)$, the interest rate $r(t)$ is normally distributed with mean $r(s) e^{-\beta(t-s)}+\frac{\alpha}{\beta}\left(1-e^{-\beta(t-s)}\right)$ and variance $\frac{\sigma^{2}}{2 \beta}\left(1-e^{-2 \beta(t-s)}\right)$. Instead of estimating $\alpha_{r}, \beta_{r}$, and $\sigma_{r}$ directly, we estimate the following functions of the parameters: $\mu=\frac{\alpha}{\beta}, \gamma=e^{-\beta \delta}$ and $V^{2}=\frac{\sigma^{2}}{2 \beta}\left(1-e^{-2 \beta \delta}\right)$, where $\delta$ denotes the time step of the observed 10-year rates $r_{0}, r_{1}, \ldots, r_{n}$ of $r$. Let $f\left(r_{i} \mid r_{i-1} ; \gamma, \mu, V^{2}\right)$ denote the probability density function of $r_{i}$ conditional on $r_{i-1}$. Hence, it follows that

$$
f\left(r_{i} \mid r_{i-1} ; \gamma, \mu, V^{2}\right)=\frac{1}{\sqrt{2 \pi} V} \exp \left(-\frac{\left(r_{i}-\left(\gamma r_{i-1}+\mu(1-\gamma)\right)\right)^{2}}{2 V^{2}}\right)
$$

Therefore, the log-likelihood function for the observed interest rates is 


$$
\operatorname{LLK}\left(\gamma, \mu, V^{2}\right)=-\frac{n}{2} \log 2 \pi-\frac{n}{2} \log V^{2}-\frac{1}{2 V^{2}} \sum_{i=1}^{n}\left(r_{i}-\gamma r_{i-1}-\mu(1-\gamma)\right)^{2}
$$

Summing over all $n$ observations and then maximizing the log-likelihood function gives $\hat{\alpha}_{r}=0.008120, \hat{\beta}_{r}=0.2168$, and $\hat{\sigma}_{r}=0.009511$. Rather than use the estimator of the volatility parameter in the simulations, we adjust the volatility parameter of the Vasicek model each month to match the basis point volatility of a one-year into ten-year swap option. The results, however, are robust to the specification of the interest rate model.

\section{A.8 Estimation Methodology}

The estimation of the model can be viewed as consisting of three steps.

1. First, we select an initial parameter vector $\theta$, where $\theta=\left\{a, b, \alpha_{w}, \alpha_{x}, \alpha_{y}\right.$, $\left.\beta_{w}, \beta_{x}, \beta_{y}, \sigma_{w}, \sigma_{x}, \sigma_{y}\right\}$.

2. Second, conditional on $\theta$ and for each month $t$ during the sample period, we solve for the values of $w_{t}, x_{t}$, and $y_{t}$ that best fit the model to the prices for the coupon stack (the cross section of mortgage-backed securities with different coupon rates) by minimizing the root mean squared error (RMSE).

Since the nonlinear structure of the prepayment function makes it difficult to express the price of mortgage-backed securities in closed-form, we use simulation to solve for the model-based mortgage-backed security values. The simulation step solves

$$
F(m, K)=\frac{1}{S\left(t_{0}\right) D\left(t_{0}\right)} \sum_{i=1}^{K} S\left(t_{i}\right) D\left(t_{i}\right) \hat{E}\left[C F_{i}\right]
$$

for given values of $w_{t}, x_{t}$, and $y_{t}$. Since $D(t)$ is computed from the Treasury yield curve and $S(t)$ has a closed-form solution, we can focus on the expectation in the equation above. We simulate paths of $r_{t}, x_{t}$, and $y_{t}$, and then compute a path of $p_{t}$ since

$$
p_{t}=x_{t}+y_{t} \max \left(0, m-a-b r_{t}\right) \text {. }
$$

We use monthly time steps, and the square-root processes are simulated following the algorithm presented in Shao (2012). From $p_{t}$, we compute the survival factors $N(t)$ for each month, and then compute the mortgage cash flows $C F_{i}$. The average cash flows along each path provides the estimate of 
the expectation. Given the value of the expectation, we then solve for the mortgage price.

The RMSE of the simulated prices and the market prices provides the objective function for the optimization. We use the controlled random search (CRS) algorithm of Kaelo and Ali (2006) to solve for the initial values of $w_{t}$, $x_{t}, y_{t}$ which minimize the RMSE for each date $t$.

3. Third, we apply the CRS algorithm to the parameter vector $\theta$ to find the vector that results in the lowest global root mean square error (RMSE). The outputs are the parameter values and the time series of state variables. 
Table A1

Data Definitions and Sources

\begin{tabular}{|c|c|c|c|}
\hline & Data & Frequency & Description and Source \\
\hline 1 & FNMA MBS Prices & Monthly & $\begin{array}{l}\text { Proprietary data set provided by a major Wall Street MBS dealer. } \\
\text { Data cross validated with Bloomberg data. }\end{array}$ \\
\hline 2 & FNMA CPR Data & Monthly & Three-month CPR prepayment rate data collected and provided by eMBS Inc. \\
\hline 3 & Treasury CMT Data & Monthly & Constant maturity Treasury rates from Federal Reserve H.15 Selected Interest Rates Release. \\
\hline 4 & Discount Function $\mathrm{D}(\mathrm{T})$ & Monthly & $\begin{array}{l}\text { Discount function out to } 30 \text { years bootstrapped from Treasury CMT rates using standard } \\
\text { cubic spline interpolation algorithm as described in Longstaff, Mithal, and Neis (2005). }\end{array}$ \\
\hline 5 & Interest Rate Volatility & Monthly & $\begin{array}{l}\text { Basis point volatility for 1-year into 10-year swaptions. Proprietary data set provided by } \\
\text { major Wall Street MBS dealer. }\end{array}$ \\
\hline 6 & FNMA Agency Credit Spread & Monthly & $\begin{array}{l}\text { Ten-year FNMA note yield over ten-year Treasury yield. Proprietary data set provided by a } \\
\text { major Wall Street MBS dealer. }\end{array}$ \\
\hline 7 & Primary Dealers' MBS Holdings & Monthly & Federal Reserve Bank of New York: http://www.newyorkfed.org/markets/gsds/search.html. \\
\hline 8 & Repo Rate & Monthly & General collateral Treasury three-month repo rate provided by Bloomberg. \\
\hline 9 & Net MBS Issuance & Monthly & Net MBS issuance in $\$$ millions provided by eMBS Inc. \\
\hline 10 & Federal Reserve MBS Purchases & Weekly & $\begin{array}{l}\text { Board of Governors of the Federal Reserve System, Mortgage-Backed Securities } \\
\text { Held by the Federal Reserve: All Maturities [MBST], retrieved from FRED, } \\
\text { Federal Reserve Bank of St Louis, https://research.stlouisfed.org/fred2/series/MBST. } \\
\text { Weekly data aggregated to monthly and quarterly frequency. }\end{array}$ \\
\hline 11 & Consumption Expenditures & Monthly & $\begin{array}{l}\text { Seasonally adjusted at annual rates. US Bureau of Economic Analysis, Personal } \\
\text { Consumption Expenditures [PCE], retrieved from FRED, Federal Reserve Bank of } \\
\text { St. Louis, https://research.stlouisfed.org/fred2/series/PCE. }\end{array}$ \\
\hline 12 & Unemployment Rate & Monthly & $\begin{array}{l}\text { Seasonally adjusted unemployment rate provided by Bureau of Labor Statistics, } \\
\text { http://data.bls.gov/timeseries/LNS14000000. }\end{array}$ \\
\hline 13 & Delinquency Rate & Quarterly & $\begin{array}{l}\text { Seasonally adjusted. Mortgage Bankers Association National Delinquency Survey, } \\
\text { provided by Bloomberg (DLQTDLQT Index). }\end{array}$ \\
\hline 14 & Foreclosure Rate & Quarterly & $\begin{array}{l}\text { Mortgage Bankers Association National Delinquency Survey, provided by } \\
\text { Bloomberg (DLQTFORE Index). }\end{array}$ \\
\hline 15 & Cash-Out Mortgage Ratio & Quarterly & $\begin{array}{l}\text { Freddie Mac, Office of Chief Economist, Cash-Out Refinance Report, 4Q 2014, } \\
\text { http://www.freddiemac.com/finance/refinance_report.html. }\end{array}$ \\
\hline
\end{tabular}


Table A1 Continued

Data
Frequency Description and Source

Monthly Monthly returns on the Barclays US Aggregate Bond Index.

Monthly Monthly valued-weighted return on all NYSE, AMEX, and NASDAQ firms,

Center for Research in Security Prices.

Monthly National Association of Home Builders Market Index. This index is based

on a monthly survey of NAHB members of the single-family housing market.

Monthly Seasonally adjusted. The outstanding amount of credit used by consumers

excluding mortgage loans. Federal Reserve, provided by Bloomberg (USHBMIDX Index).

Quarterly Loan to value ratios for all conventional loans. Data reported by the

Monthly Interest Rate Survey (MIRS) of the Federal Housing Finance Agency (FHFA).

21 Bank Tightening Index

Quarterly Percentage of banks tightening mortgage lending standards from Board of Governors

of the Federal Reserve System, Net Percentage of Banks Tightening Standards for

Mortgage Loans [H0SUBLPDHMSNQ], retrieved from FRED, Federal Reserve Bank of St. Louis

https://research.stlouisfed.org/fred2/series/H0SUBLPDHMSNQ.

22 Consumer Confidence Index Monthly 
Table A2

Cash Flow Time Line for a Hypothetical 30-Year Fannie Mae TBA trade. This table shows the key events and cash flows surrounding a 30-year Fannie Mae TBA trade executed on March 31.

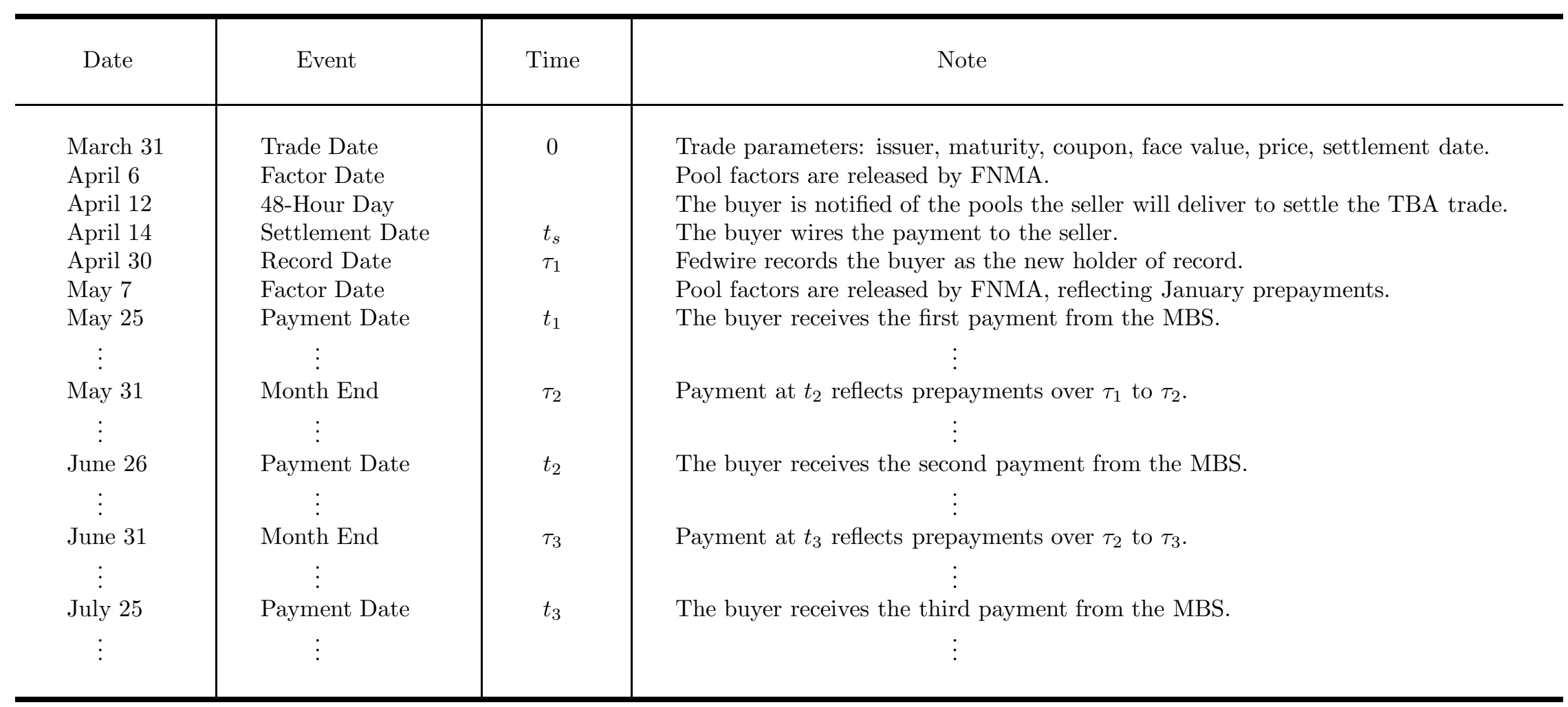

